\title{
Using Securities Market Information for Bank Supervisory Monitoring
}

\author{
John Krainer and Jose A. Lopez \\ Federal Reserve Bank of San Francisco \\ Economic Research Department \\ 101 Market Street \\ San Francisco, CA 94105 \\ john.krainer@sf.frb.org \\ jose.a.lopez@sf.frb.org
}

Draft date: May 5, 2004

\begin{abstract}
Bank supervisors in the United States conduct comprehensive on-site inspections of bank holding companies (BHCs) and assign them a supervisory rating meant to summarize their overall condition. We develop an empirical forecasting model of these ratings that combines supervisory and securities market data. We find that securities market variables, such as BHC stock returns and bond yield spreads, improve the model's in-sample fit. We also find that debt market variables provide more information on supervisory ratings for BHCs closer to default, while equity market variables provide more information for those further from default. In out-ofsample forecasting, we find that the accuracy of the model with both equity and debt variables is little different from the accuracy of a model based on supervisory information alone. However, the model with securities market data identifies additional ratings downgrades, which supervisors would probably value enough to warrant the use of this extended model for off-site monitoring purposes.
\end{abstract}

\footnotetext{
Acknowledgments: The views expressed here are those of the authors and not necessarily those of the Federal Reserve Bank of San Francisco or the Federal Reserve System. We thank Rob Bliss for generously sharing his bank holding company debt database with us. We thank Fred Furlong, Reint Gropp, and seminar participants at the Bank of England, the Basel Committee's Research Task Force on Banking Supervision, and the Chicago Conference on Bank Competition and Structure for helpful suggestions. We thank Judy Peng Feria, Ryan Stever, and Chishen Wei for research assistance.
} 


\title{
Using Securities Market Information for Bank Supervisory Monitoring
}

\begin{abstract}
Bank supervisors in the United States conduct comprehensive on-site inspections of bank holding companies (BHCs) and assign them a supervisory rating meant to summarize their overall condition. We develop an empirical forecasting model of these ratings that combines supervisory and securities market data. We find that securities market variables, such as BHC stock returns and bond yield spreads, improve the model's in-sample fit. We also find that debt market variables provide more information on supervisory ratings for BHCs closer to default, while equity market variables provide more information for those further from default. In out-of-sample forecasting, we find that the accuracy of the model with both equity and debt variables is little different from the accuracy of a model based on supervisory information alone. However, the model with securities market data identifies additional ratings downgrades, which supervisors would probably value enough to warrant the use of this extended model for off-site monitoring purposes.
\end{abstract}




\section{Introduction}

Concerns about the economic damage associated with bank runs have led policymakers in the United States to provide the banking sector with a deposit insurance safety net. In exchange for this safety net, banks and their bank holding companies (BHCs) are subject to much more regulatory oversight than firms in other sectors. The most comprehensive form of banking supervision in the United States is the on-site inspection, where a team of supervisors visits an institution and analyses its operations in detail. At the conclusion of the inspection, the supervisors assign the institution a rating, known as a BOPEC rating, that summarizes their opinion of the BHC's overall financial condition. Note that BOPEC ratings are confidential and are not publicly available.

Between on-site inspections, supervisors engage in off-site monitoring, which largely consists of analyzing quarterly reports from the institutions in question. The aim of this paper is to investigate the effectiveness of off-site monitoring models in predicting BOPEC ratings . ${ }^{1}$ In particular, we examine whether BHC securities market data, both from the equity and debt markets, are useful as explanatory variables in these models. We also examine which securities market variables appear to be most useful for predicting ratings changes, and under what conditions.

Securities market prices should, in an ideal world, tell supervisors all they need to know about BHC conditions and their likelihoods of failure. In practice, however, there are a number of frictions that make our question worthy of empirical research. First, perceptions of possible government support for a struggling BHC, and the safety net in general, might reduce investor incentives to monitor, thus affecting the sensitivity of security prices to changes in BHC conditions. Second, since banks specialize in solving problems of asymmetric information, the loans they hold as assets may be difficult for outside investors to value. This problem, like the first, might make security prices less sensitive to changes in asset value. Finally, supervisors have access to information that BHCs are not normally required to disclose to investors, raising

\footnotetext{
${ }^{1}$ Note that in this paper we focus on supervisory ratings and not defaults, another key supervisory concern. There exists an extensive literature on bank default dating back to Meyer and Pifer (1970), Sinkey (1975), and Pettway and Sinkey (1980).
} 
questions of whether securities prices can tell supervisors anything they do not already know.

To date, much of the literature on this subject has focused on the information content in subordinated debt prices, primarily because the concerns of debt holders are thought to be more closely aligned with those of supervisors; see the study by the Board of Governors of the Federal Reserve System (1999) for a survey. Curiously, there is less academic research on assessing whether equity markets offer ways to forecast changes in BHC conditions. Krainer and Lopez (2003a) conducted event studies to examine whether equity markets anticipate changes in supervisory BOPEC ratings and found evidence of a meaningful response up to a year prior to BOPEC changes.

A few studies, such as Berger et al. (2000) and Gropp et al. (2003), use both equity and bond market data to predict changes in BHC ratings and conditions. They find that both sets of securities market information are useful for this purpose, but in different ways. The motivation for comparing these two sets of investor information sets arises naturally. If a firm issues both equity and debt, the price sensitivity of the two instruments to changes in the underlying asset value will depend on how close the firm is to default. If the market value of the firm's assets are worth less than the face value of the debt, the seniority of debt over equity implies that changes in asset values will prompt large changes in debt prices and have a relatively smaller impact on equity prices. Debt prices should be much less sensitive to changes in asset values when the firm is far from default because gains (or losses) in asset values at that point accrue mainly to the equity holders.

In this paper, we investigate the potential contributions of both equity and debt market information to the supervisory monitoring of BHCs using an off-site monitoring model for BOPEC ratings. We measure their contributions relative to a model based on supervisory data alone. $^{2}$ From the equity market, we consider two measures based on a decomposition of individual BHC stock returns into an abnormal return constructed over a period leading up to the assignment of the BOPEC rating and the fitted return derived from a two-factor model. From the

2 Throughout the paper we will use the term "supervisory data" to mean data generated by supervisors as part of the BHC quarterly report or as part of the supervisory process. We do not mean to imply that securities market data are not currently used by supervisors. 
debt market, we examine a BHC's weighted average bond yield adjusted for maturity, external rating and lagged BOPEC rating. Our empirical results suggest that all of these securities market variables contribute to the model's in-sample fit. We further find an asymmetric contribution from these variables; that is, in a model of BOPEC changes, the magnitude of the coefficients on equity variables are larger for BHCs further from default, while the coefficients on the debt variables are larger for BHCs close to default.

Turning to out-of-sample forecasting, we find little evidence of improved forecast accuracy after incorporating securities market information into the model. That is, the accuracy of BOPEC forecasts based on supervisory data alone is not statistically different from that of BOPEC forecasts generated by the model augmented with securities market data. However, we find that while the forecasts are not different in a statistical sense, they are different in an economic sense. The forecasts based on the model incorporating securities market information identify additional BOPEC rating changes, especially downgrades, of publicly traded BHCs that were not identified by the core supervisory model. Given the supervisory objective function that values early warnings of potential downgrades, this identification of additional correct BOPEC changes could outweigh the cost of the additional false signals.

The paper proceeds as follows. In section II, we provide a brief overview of the supervisory process for BHCs in the U.S. We also provide a brief survey of the academic literature on off-site monitoring models and the use of securities market information for supervisory monitoring. In section III, we estimate our proposed BOPEC off-site monitoring model (BOM) using both supervisory and securities market variables. We also examine the differential impact of the securities market variables based on the BHC's relative distances from their default points. In section IV, we examine the various model specifications' out-of-sample performance using a statistical and a supervisory objective function. The latter suggests that securities market information should be useful for supervisory monitoring purposes. Section V concludes. 


\section{The U.S. supervisory process and literature review}

\section{II.A. The U.S. supervisory process}

The Federal Reserve is the supervisor of bank holding companies (BHCs) in the United States. Full-scope, on-site inspections of BHCs are a key element of this supervisory process. These inspections are generally conducted on an annual basis, particularly for the case of large and complex BHCs. ${ }^{3}$ Limited and targeted inspections that may or may not be conducted on-site are also carried out. In this paper, we focus on full-scope, on-site inspections since they provide the most comprehensive supervisory assessments of BHCs.

At the conclusion of an inspection, supervisors assign the BHC a numerical rating called a composite BOPEC rating that summarizes their opinion of the BHC's overall health and financial condition. The BOPEC acronym stands for the five key areas of supervisory concern: the condition of the BHC's Bank subsidiaries, Other nonbank subsidiaries, Parent company, Earnings, and Capital adequacy. BHCs with the best performance are assigned a BOPEC rating of one, while those with the worst performance are given a BOPEC rating of five. A rating of one or two indicates that the BHC is not considered to be of supervisory concern. Note that BOPEC ratings, as well as all other inspection materials, are confidential and are not made publicly available. $^{4}$

Between on-site inspections when private supervisory information cannot be gathered as readily, supervisors monitor BHCs using an off-site monitoring system based on quarterly regulatory reports filed by BHCs and their subsidiary banks. This off-site monitoring system is primarily based on three information sources. The first source, known as the BHC Performance Report, is a detailed summary of their quarterly Y-9C regulatory reporting forms. ${ }^{5}$ As of March 1999, the report summarized approximately 800 BHC variables across several years. From this report, certain variables are compared to supervisory performance criteria, and if a BHC fails to

\footnotetext{
${ }^{3}$ A complex BHC is defined as one with material credit-extending nonbank subsidiaries or debt outstanding to the general public. See DeFerrari and Palmer (2001) for an overview of the supervisory process for large, complex banking organizations.

${ }^{4}$ For an international survey of supervisory bank rating systems, see Sahajwala and Van der Bergh (2000).

${ }^{5}$ For a complete description of the BHC Performance Report, see the user guide at http://www.federalreserve.gov/boarddocs/supmanual/bhcpr/bhcpr_2000_access.pdf
} 
meet these criteria, it is noted as an exception that requires further monitoring.

The second source of information for off-site BHC monitoring is the supervisory CAMELS ratings assigned to banks within the holding company. As with BOPEC ratings, CAMELS ratings are confidential ratings that are assigned after a bank examination. The acronym refers to the six key areas of concern: the bank's capital adequacy, asset quality, management, earnings, liquidity, and sensitivity to risk. The composite CAMELS rating also ranges in integer value from one to five in decreasing order (i.e., banks that perform best are assigned a rating of one). Since the condition of a BHC is closely related to the condition of its subsidiary banks, the off-site BHC surveillance program includes monitoring recently assigned CAMELS ratings.

As with on-site BHC inspections, on-site bank examinations occur at approximately a yearly frequency, which is long enough for the gathered supervisory information to decay and become less representative of the bank's condition. ${ }^{6}$ To address this issue, the Federal Reserve instituted an off-site monitoring system for banks, known as the System for Estimating Examiner Ratings (SEER), in 1993. The SEER system actually consists of two separate models that forecast bank failures over a two-year horizon as well as bank CAMELS ratings for the next quarter. The model that we are most interested in here is the latter, which is an ordered logit model with five categories corresponding to the five possible values of the CAMELS rating. The model is estimated every quarter in order to reflect the most recent relationship between the selected financial ratios and the two most recent quarters of CAMELS ratings. Significant changes in a bank's CAMELS rating as forecasted by the SEER model could be sufficient to warrant closer monitoring of the bank. The off-site BHC surveillance program also explicitly monitors the SEER model's forecasted CAMELS ratings.

A third information source is BHC securities market information, when available. For example, if a BHC exhibits irregular stock price movements, it can be noted as an exception that requires further monitoring during the regular surveillance process.

\footnotetext{
6 See Cole and Gunther (1995) as well as Hirtle and Lopez (1999) for further discussion of this issue.
} 


\section{II.B. Literature review}

An extensive academic literature regarding the complementarity of supervisory and market monitoring of BHCs and their banks already exists; see Flannery (1998) for a survey. In broad terms, these studies have examined securities market monitoring of BHCs with respect to their publicly traded equity and debt.

\section{II.B.1. Equity market information}

Only about $26 \%$ of all BHCs were publicly owned as of mid-1998 according to our dataset, but these BHCs accounted for about $85 \%$ of total BHC assets. Given that such a large percentage of BHC assets are publicly traded, it seems reasonable to expect that the equity market could provide relevant information on the condition of these assets. Research on this topic has proceeded on two different fronts. First, researchers have questioned whether the supposed opaqueness of bank assets makes it difficult for equity investors to value bank stocks relative to non-banking stocks. Recent evidence by Flannery et.al. (2000) indicates that BHCs appear to be as or more transparent than matched non-bank firms with respect to equity market microstructure properties, such as trading volume and analyst coverage. Note, however, that Morgan (2003) found evidence that financial firms experience more split ratings from rating agencies, suggesting that financial assets may be more opaque.

A second branch of the literature assumes that the equity market is capable of valuing BHC assets and looks instead at possible overlaps between the market and supervisory information sets. An early study by Shick and Sherman (1980) found preliminary evidence that BHC stock prices do reflect changes in BHC condition, measured as changes in their banks' CAMELS ratings. A recent study by Cannata and Quagliariello (2003) found that equity market variables help explain supervisory ratings of Italian banks.

Krainer and Lopez (2003a) conducted event studies to examine whether equity markets anticipate changes in supervisory BOPEC ratings and found evidence of a meaningful response up to a year prior to BOPEC changes. In a related study, Krainer and Lopez (2003b) examine the contribution of equity market variables to supervisory monitoring within the context of a BOPEC off-site monitoring model. They find that these variables do improve the model's in-sample fit 
relative to using just supervisory variables. Although the two models' out-of-sample performances are not statistically different, the authors conclude that equity market information should be incorporated into supervisory monitoring models. ${ }^{7}$

Berger and Davies (1998) conduct a different study; using an event study framework, they examine whether daily stock prices react to CAMELS rating changes. Even though CAMELS are confidential, they find that BHC stock prices do respond to these changes, implying that supervisory assessments do provide valuable information and that the equity market can detect it.

\section{II.B.2. Debt market information}

About 3.5\% of all BHCs in our sample as of mid-1998 had outstanding publicly traded debt at the BHC or bank level, although these BHCs accounted for $70 \%$ of total BHC assets at that time. Many of the same exercises described above have also been conducted using debt market information, particularly subordinated debt market information. Many studies of BHC subordinated debt have compared the responsiveness of these yields to accounting measures of BHC performance, not supervisory ratings; see Board of Governors (1999) for a survey. Flannery and Sorescu (1996) found that BHC yield spreads were correlated with BHC risk measures over the period from 1983 to 1991 and that this correlation was higher in the latter part of the sample due to a weakening of assumed government guarantees on BHC liabilities. However, Covitz et. al. (2002) found that, after adjusting for the dependence of the debt's liquidity on the risk-sensitive managerial decision of whether to issue the debt, market discipline was of the same magnitude over the period from 1986 to 1999.

In a similar spirit to the work of Berger and Davies (1998), DeYoung et.al. (2001) examine if and how supervisory information makes its way into the BHC debt market. They find that supervisory information significantly affects contemporaneous and subsequent changes in the spreads on bank debentures. Specifically, they find that the private supervisory information component of bank CAMELS ratings impacts debenture spreads several months after the

\footnotetext{
${ }^{7}$ Similar results and conclusions are presented by Curry et al. (2001), Elmer and Fissel (2001), Hall et al. (2001), Gunther et al. (2001) and Curry et al. (2003).
} 
CAMELS assignment. Since the interests of bank subordinated debt holders and bank supervisors are supposedly aligned, several studies have advocated that subordinated debt prices be incorporated into the supervisory process. ${ }^{8}$ Evanoff and Wall (2002) examine this proposition directly by testing the degree to which subordinated debt spreads provide supervisors with additional information. In their work, they model changes in the supervisory ratings of banks and BHCs with outstanding subordinated debt over the period from 1990 to 1999 as a function of lagged subordinated debt spreads and regulatory capital ratios. They find that subordinated debt spreads do as well or better than any of the capital ratios at explaining supervisory ratings. Our paper pursues a similar line of analysis, but also includes equity market variables in the analysis.

\section{II.B.3. Equity and debt market information}

In our sample for the period from 1990 through mid-1998, almost 3\% of all BHCs had both public equity and debt outstanding, but these BHCs accounted for two-thirds of total BHC assets. Given the large percentage of these assets that are traded in the securities markets, it seems reasonable to examine both sets of market signals. ${ }^{9}$

To our knowledge, the first paper to analyze signals from both BHC securities markets was Pettway (1976). Several recent studies have addressed this issue using data mainly from the 1990s. ${ }^{10}$ For example, Berger et. al. (2000) examine the timeliness and accuracy of supervisory and market assessments of the condition of large BHCs. They find that equity market assessments based on abnormal returns and changes in large shareholdings are not strongly

\footnotetext{
${ }^{8}$ One objection to this proposition is found in Bliss (2000), who shows that supervisory interests may diverge from bondholder interests since both parties may not necessarily agree on the relative riskiness of different banks or bank portfolios.

9 See Basel Committee on bank Supervision (2003) for an overview of the markets for bank equity and debt securities.

10 Note that Karafiath et al. (1991) examine the response of BHC equity and debt securities to 1987 Brazilian debt moratorium. In contrast to equity price movements, the cross-section of weekly bond yields in excess of Treasury note yields were not significantly different from zero. One interpretation for this differential response is that market participants expected lower bank profits due to the crisis, but not defaults and bond losses.
} 
related to supervisory assessments based on BOPEC ratings. Thus, market assessments appear to focus on different aspects of BHC performance than do supervisory assessments. Furthermore, they find that, after accounting for market assessments, supervisory variables do not contribute substantially to the modeling of future indicators of BHC performance, such as changes in nonperforming loans. Overall, their findings suggest that supervisors, bond market participants and equity market participants produce complementary information on BHC performance.

While these authors analyze supervisory ratings for U.S. BHCs, Gropp and Richards (2001) as well as Gropp, Vesala, and Vulpes (2003) examine agency ratings for European banking organizations. In the latter study, the authors examine the ability of equity market variables and subordinated bond spreads for European banks to signal changes in bank financial conditions. Using ordered logit models at several horizons and a proportional hazard model, they find that both equity-based measures of distance-to-default and subordinated debt spreads are useful for detecting changes in bank ratings. Interestingly, they find that the distance-to-default measure performs less well closer to default and that subordinated debt spreads seem to have signal value only close to default. The authors argue that their empirical results provide support for the use of securities market information in supervisor's early warning models.

Finally, González-Rivera and Nickerson (2003) use a Kalman-filter algorithm to find a common factor among the price fluctuations of BHC equity and bond debt issues. They find that this common factor could be used to construct a leading indicator of BHC conditions.

\section{II.C. The BOPEC ratings sample}

The core database for our analysis is the set of supervisory BOPEC ratings assigned between the first quarter of 1990 and the second quarter of 1998. The sample endpoint is dictated by the availability of the bond dataset. ${ }^{11}$

We chose to analyze only BOPEC ratings assigned after an on-site, full-scope inspection. This requirement reflects the concern that limited and targeted inspections produce a less

\footnotetext{
11 We are grateful to Rob Bliss for sharing his BHC bond database with us. A complete description of the database is presented in Bliss and Flannery (2001). The last quarter of bond data is the first quarter of 1998, which aligns with the second quarter of 1998 in the BOM model.
} 
comprehensive supervisory information set than a full inspection. Our sample of BOPEC ratings is further refined to include only inspections of top-tier BHCs with identifiable lead banks, four quarters of available supervisory data and prior BOPEC ratings. We focus on top-tier BHCs since they are typically the legal entities within the banking group that issues publicly-traded equity. The lead bank designation is often provided by banks in their regulatory filings. When such self-reporting is not available, we assign the lead-bank designation to the largest bank within the group. We need the BHCs in our sample to have identifiable lead banks in order to directly link their BOPEC ratings to their lead bank's CAMELS ratings. ${ }^{12}$ Finally, we require each BHC to have at least four quarters and a lagged BOPEC rating in order to avoid issues regarding de novo BHCs and new BHCs arising from mergers. In addition, four quarters of supervisory data are required to calculate certain explanatory variables for the model described below.

Table 1 summarizes our sample of 3,010 BOPEC ratings assigned to 1,034 unique entities. Almost $65 \%$ of the BHCs in the sample are relatively small, with less than $\$ 1$ billion in total assets. Slightly more inspections occurred in the first half of the sample than in the second half, reflecting consolidation in the U.S. banking sector. For publicly traded BHCs, there are 1,291 BOPEC assignments corresponding to 363 unique entities. Note that public BHCs are generally larger than privately held BHCs, with a greater percentage having total assets ranging between $\$ 1$ billion and $\$ 100$ billion. Of the 41 BOPECs assigned to the largest BHCs, 39 are of public BHCs. With respect to BHCs with public debt outstanding, this subsample contains 309 BOPEC ratings corresponding to 63 unique BHCs. Again, these BHCs are typically larger than those in the full sample with almost all BHCs having between $\$ 1$ billion and $\$ 100$ billion in assets. Finally, there are 283 BOPEC ratings corresponding to 58 unique BHCs that have both publicly traded equity and debt outstanding. As expected, these BHCs are also typically larger with all having more than $\$ 1$ billion in assets.

Tables 2A-2D present the distribution of BOPEC ratings assigned in each year for all BHCs, for BHCs with publicly traded equity, for BHCs with publicly traded bonds, and BHCs

\footnotetext{
12 Note that this restriction does not imply that we limited the sample to single-bank BHCs. We simply focus on the CAMELS rating for a BHC's lead bank, whether self-identified or identified by asset size.
} 
with both public equity and debt, respectively. The majority of the ratings fall in the upper two categories, indicating that a BHC's financial condition and risk profile are of little supervisory concern. For the full sample, while the distribution of ratings fluctuates over time, the percentage of ratings in the top two categories never falls below 63\%. The maximum value is $96.5 \%$ in 1998 . Note that there are relatively few inspections culminating in a BOPEC rating of 4 or worse, since both supervisors and bankers actively try to prevent this outcome and since the banking industry performed quite well during the 1990s.

Tables 3A-3D present the pattern of BOPEC ratings changes in our sample. The most frequent outcome is no change in BOPEC rating, accounting for between $69 \%$ and $87 \%$ of the annual totals for the full sample. The pattern of BOPEC upgrades and downgrades fluctuates dramatically over the course of the sample time period. For all four samples, from 1990 through 1992, more downgrades occurred than upgrades, but from 1993 through the end of the sample, the pattern was reversed. The pattern appears to follow the general trends in U.S. banking and macroeconomic conditions during the 1990s.

\section{Multivariate analysis using the ordered logit model}

Our proposed BOPEC off-site monitoring (BOM) model is an ordered logit model, and is similar in structure to the SEER model for CAMELS ratings; see Krainer and Lopez (2003a) for further details. We assume that the BOPEC rating assigned to $\mathrm{BHC} \mathrm{i}$ in quarter $\mathrm{t}$, denoted $\mathrm{BP}^{*}{ }_{\mathrm{it}}$, can be modeled as

$$
\mathrm{BP}_{\mathrm{it}}^{*}=\left(\beta+\gamma_{\mathrm{E}} \mathrm{I}_{\mathrm{Eit}-1}+\gamma_{\mathrm{D}} \mathrm{I}_{\text {Dit-1 }}\right) \mathrm{x}_{\mathrm{it}-2}+\pi_{\mathrm{E}} \mathrm{z}_{\mathrm{Eit}-1} \mathrm{I}_{\mathrm{Eit}-1}+\pi_{\mathrm{D}} \mathrm{z}_{\text {Dit-1 }} \mathrm{I}_{\text {Dit-1 }}+\varepsilon_{\mathrm{it}} .
$$

In this specification, $\mathrm{x}_{\mathrm{it}-2}$ is a $(\mathrm{k} \times 1)$ vector of supervisory variables unique to $\mathrm{BHC} \mathrm{i}$ observed two quarters prior to the BOPEC assignment. We chose to lag the supervisory variables by two quarters because these are often the most recent data available at the time of inspection. ${ }^{13}$ The indicator variables $\mathrm{I}_{\mathrm{Eit}-1}$ and $\mathrm{I}_{\text {Dit-1 }}$ represent BHCs with publicly traded equity and debt, respectively, a quarter prior to the BOPEC assignment. The interaction terms allow us to control for possible differences between BHCs with and without public equity and debt. The $\mathrm{z}_{\mathrm{Eit}-1}$ and

13 See Gunther and Moore (2003) for further discussion. 
$\mathrm{z}_{\mathrm{Dit}-1}$ terms are vectors of equity and debt market variables, respectively, that correspond to BHC $\mathrm{i}$ at time $\mathrm{t}-1$, one quarter before the BOPEC assignment. The supervisory variables and the securities market variables enter into the model with different lags since securities market information is available on a more timely basis than the supervisory variables we use. The error term $\varepsilon_{\mathrm{it}}$ has a standard logistic distribution.

\section{III.A. Supervisory Variables}

The choice of which supervisory variables to include in $\mathrm{x}_{\mathrm{it}-2}$ is challenging. No simple behavioral models exist of how supervisors assign BOPEC ratings and, as mentioned, there are more than 800 variables at the supervisors' disposal for this purpose. For this study, we selected nine explanatory variables that are reasonable proxies for the five components of the BOPEC rating as well as the lagged BOPEC rating. As in Krainer and Lopez (2003a,b), we chose a parsimonious specification in the hopes of generating reasonable out-of-sample forecasts. Additionally, we face the practical concern that many fewer BOPEC ratings are available in any given subsample period than are available in our full sample.

In this model, we include the lagged BOPEC rating to capture ratings persistence as well as to serve as a proxy for omitted supervisory variables that contribute to BOPEC assignments. Our supervisory variables are summarized in Table 4. The first variable is the natural log of total $\mathrm{BHC}$ assets, which is our control variable for BHC size. The next four variables are used to capture the supervisory concerns regarding the BHC's bank subsidiaries, as summarized in the "B" component of the rating. The second variable is the CAMELS rating of the BHC's lead bank. The third variable is the ratio of the BHC's nonperforming loans, nonaccrual loans, and other real estate owned to its total assets. This variable proxies for the health and performance of the BHC's loan portfolio. The fourth variable is the ratio of the BHC's allowances (or provisions) for losses on loans and leases to its total loans, another proxy for the health and performance of the BHC's loan portfolio.

The fifth variable is an indicator of whether the BHC has a Section 20 subsidiary, which is a subsidiary that can engage in securities activities that commercial banks were generally not permitted to engage in before the Gramm-Leach-Bliley Act of 1999. This variable is a proxy for 
the scale of the BHC's nonbank activities, and thus speaks to the "O" component of the BOPEC rating. We also include as the sixth variable the ratio of a BHC's trading assets to its total assets as a proxy of its non-banking activities, whether conducted in banking or non-banking subsidiaries. ${ }^{14}$

The seventh variable is the so-called "double leverage" ratio between the BHC and its lead bank, which is the ratio of the lead bank's equity capital to that of the parent's equity capital. This variable provides a measure of the soundness of the parent $\mathrm{BHC}$, indicating the extent to which the parent's equity capital can be used to buffer against damage to the lead bank's equity capital. We use this variable as a proxy for the condition of the parent BHC as summarized in the "P" component of the BOPEC rating. The eighth variable is the BHC's return on average assets (ROAA), defined as the ratio of the four-quarter average of the BHC's net income to the four-quarter average of its assets. This variable is used to proxy for the "E" component of the BOPEC rating. The ninth variable is the BHC's ratio of equity capital to its total assets. This variable is used to proxy for the "C" component of the BOPEC rating. ${ }^{15}$

We refer to the version of the BOM model based on just these supervisory variables as the core model. The equity BOM model extends the core model to include the variables from the equity markets. The debt BOM model extends the core model to include the bond market variables. Finally, the extended BOM model estimates all of the parameters in the equation.

\section{III.A.1. Equity Market Variables}

The equity market variables used in this study are based on observed stock returns over a six-month period that ends one quarter prior to the beginning of the on-site inspection leading to a BOPEC assignment. Our two variables are motivated by the common decomposition of cumulative stock returns into systematic and idiosyncratic components; see Campbell et al. (1997).

\footnotetext{
14 Note that the trading assets variable as currently reported first became available in the first quarter of 1995. Before then, we proxy for BHC trading assets using the sum of the self-reported replacement cost of interest rate and foreign exchange derivative contracts.

15 A variety of capital measures have been used in previous studies, such as Evanoff and Wall (2000) and Estrella et al. (2000). We chose a simple measure to facilitate comparison over the entire period.
} 
We decompose monthly BHC stock returns, denoted as $\mathrm{R}_{\mathrm{it}}$, before a BOPEC assignment into a systematic return, denoted $\mathrm{SR}_{\mathrm{it}}$, and an idiosyncratic, or abnormal return, denoted $\mathrm{AR}_{\mathrm{it}}$. The decomposition is based on a two-factor market model; i.e.,

$$
\mathrm{R}_{\text {it }}=\alpha+\beta_{1} \mathrm{R}_{\mathrm{mt}}+\beta_{2} \mathrm{f}_{\mathrm{t}}+\beta_{1} \mathrm{v}_{\mathrm{it}},
$$

where $\mathrm{R}_{\mathrm{mt}}$ is the monthly return on the CRSP value-weighted index, $\mathrm{f}_{\mathrm{t}}$ is the monthly change in the federal funds rate, and $v_{\mathrm{it}}$ is a normally distributed error term. For each BOPEC assignment in our sample, the regression's parameters are estimated using monthly data for a period of at least two years ending at the month one year prior to the assignment quarter's end. The $\mathrm{SR}_{\mathrm{it}}$ variables for the twelve months between the end of the estimation period and prior to a BOPEC assignment are calculated as $\mathrm{SR}_{\mathrm{it}}=\hat{\alpha}+\hat{\beta}_{1} \mathrm{R}_{\mathrm{mt}}+\hat{\beta}_{2} \mathrm{f}_{\mathrm{t}}$ and the corresponding $\mathrm{AR}_{\mathrm{it}}$ variables are simply the difference between the realized return and the systematic return, $\mathrm{AR}_{\mathrm{it}}=\mathrm{R}_{\mathrm{it}}-\mathrm{SR}_{\mathrm{it}}$.

The stock market variables are intended to pick up changes in BHC condition that occur between inspections and are relevant to the eventual BOPEC assignment, but not in the supervisory data used for the regressions. Thus, the stock market variables are used in eventstudy fashion, where we cumulate systematic and abnormal returns over a window leading up to the inspection. Define the cumulative return, the cumulative systematic return, and the cumulative abnormal return, between months $\tau_{1}$ and $\tau_{2}$ as

$$
\begin{aligned}
& \operatorname{CR}_{\mathrm{i}}\left(\tau_{1}, \tau_{2}\right)=\sum_{\mathrm{j}=\tau_{1}}^{\tau_{2}} \mathrm{R}_{\mathrm{ij}}, \\
& \operatorname{CSR}_{\mathrm{i}}\left(\tau_{1}, \tau_{2}\right)=\sum_{\mathrm{j}=\tau_{1}}^{\tau_{2}} \operatorname{SR}_{\mathrm{ij}}, \\
& \operatorname{CAR}_{\mathrm{i}}\left(\tau_{1}, \tau_{2}\right)=\sum_{\mathrm{j}=\tau_{1}}^{\tau_{2}} \mathrm{AR}_{\mathrm{ij}} .
\end{aligned}
$$

We convert these stock return variables to the quarterly frequency of the supervisory data by setting $\tau_{1}$ to $\mathrm{t}-12$ months prior to the inspection, and varying $\tau_{2}$ from $\mathrm{t}-9$ months to $\mathrm{t}-3$ months prior to the inspection. In the empirical work to follow, the cumulative return at time $\mathrm{t}-1, \mathrm{CR}_{\mathrm{it}-1}$, is the return between month $\mathrm{t}-12$ and month $\mathrm{t}-3$. As an example, consider an inspection in the 
last quarter of the year. The cumulative return is the sum of the nine monthly returns beginning in January of that year and ending in September of the same year. The corresponding systematic and idiosyncratic component returns are formed in the same way.

To permit comparison across BHCs and across time, we standardize the cumulative returns using the estimated standard errors for $\mathrm{CAR}_{\mathrm{it}-1}$, as defined in Campbell et al. (1997). The standardized form of these variables is

$$
\frac{\mathrm{CR}_{\mathrm{it}-1}}{\sqrt{\operatorname{var}\left(\mathrm{CAR}_{\mathrm{it}-1}\right)}}=\frac{\mathrm{CSR}_{\mathrm{it}-1}}{\sqrt{\operatorname{var}\left(\mathrm{CAR}_{\mathrm{it}-1}\right)}}+\frac{\mathrm{CAR}_{\mathrm{it}-1}}{\sqrt{\operatorname{var}\left(\mathrm{CAR}_{\mathrm{it}-1}\right)}},
$$

or equivalently, $\mathrm{SCR}_{\mathrm{it}-1}=\mathrm{SCSR}_{\mathrm{it}-1}+\mathrm{SCAR}_{\mathrm{it}-1}$. We use both the $\mathrm{SCSR}_{\mathrm{it}-1}$ and $\mathrm{SCAR}_{\mathrm{it}-1}$ variables in the extended BOM model, and they should indicate whether general market movements as well as idiosyncratic BHC stock returns help explain BOPEC assignments.

The motivation behind using stock market data lies in the hope that there is some agreement between stock market investors and supervisors on what constitutes healthy financial condition. Stock market investors are clearly not trying to forecast BOPEC ratings. However, if the same financial developments that lead to supervisory rating changes also lead to changes in expected stock returns, it is possible that supervisors could use stock market signals as an additional off-site monitoring signal. BHC stock price changes that are unusually large in magnitude with respect to general market activity may signal changes in condition that will eventually lead to a ratings change. The SCAR variable is designed specifically for identifying which stock price changes are "unusually large." However, relying exclusively on SCARs for market signals may cause us to miss important information available from the broader stock market. For example, an economy-wide shock that lowers returns for all stocks might not translate into abnormally negative returns for any particular BHC, but could very well be an early indicator for changes in all supervisory ratings. To address this concern, we include the SCSR variable in our regressions. Hence, $\mathrm{z}_{\mathrm{Eit}}=\left[\mathrm{SCSR}_{\mathrm{it}}, \mathrm{SCAR}_{\mathrm{it}}\right]$.

For a variety of reasons, these equity market variables are not available for all publicly traded BHCs over the entire sample period. For example, we cannot generate reliable values when a BHC does not have at least five years of stock return data with which to estimate the 
two-factor market model. To address this issue, we replaced these missing values with the variable's in-sample mean for the available observations, as per Griliches (1986). This adjustment was also used for the values corresponding to private BHCs, which would otherwise be zero. We also include corresponding fixed effects to account for this data adjustment. This procedure does not affect the model's coefficient estimates for the variables with missing equity market values, but allows us to use the entire sample in our estimation.

\section{III.A.2. Debt Market Variables}

The debt market variables used in this study are adjusted bond yields from the Warga/Lehmann Brothers Corporate Bond Database, as used by Bliss and Flannery (BF, 2001). Note that this database includes both subordinated and non-subordinated BHC debt. ${ }^{16}$ There are two empirical issues that are unique to bond data. First, in cases where a BHC has multiple outstanding bonds, it is necessary to compress the multiple market signals into a single observation. As per BF, our BHC bond yields are a weighted average, where the weights correspond to the size of the issue relative to the BHC's total amount of bonds outstanding in the quarter.

Second, as with the equity market variables, we would like to have some measure of what constitutes an abnormal change in yield. Here, we follow the BF procedure of computing debt spreads from bond price indices based on term-to-maturity and ratings. The BF ratings buckets consist of 11 categories corresponding to Moody's ratings and three term-to-maturity categories. ${ }^{17}$ The BF indices allow us to study debt yields relative to an index of similar bonds drawn from all industries. We also adjusted the BHC yield spreads to account for their current BOPEC ratings.

To summarize, for $\mathrm{BHC} \mathrm{i}$ with BOPEC rating $\mathrm{j}$ at time $\mathrm{t}$, we define the yield on a bond (or a weighted average of several bonds) with terms k (i.e., maturity and Moody's rating) as $\mathrm{y}_{\mathrm{ijkt}}$.

\footnotetext{
${ }^{16}$ For a discussion of the market for BHC subordinated debt in the United States, see Board of Governors of the Federal Reserve System (1999), Hancock and Kwast (2001), Goyal (1998) and Basel Committee on Banking Supervision (2003).

${ }^{17}$ The '+' or '-' qualifiers attached to the basic rating definitions are suppressed. The maturity buckets are less than 5 years, 5 to 10 years, and greater than 10 years.
} 
We then constructed the yield spread $\mathrm{s}_{\mathrm{ijkt}}$ relative to the corresponding BF based on terms $\mathrm{k}$; i.e.,

$$
\mathrm{s}_{\mathrm{ijkt}}=\mathrm{y}_{\mathrm{ijkt}}-\overline{\mathrm{y}}_{\mathrm{kt}}
$$

where $\bar{y}_{k t}$ is the yield on an index of like-termed bonds. We then further adjusted the yield spread to account for the BHC's corresponding BOPEC rating j; i.e.,

$$
\mathrm{d}_{\mathrm{ijkt}}=\mathrm{s}_{\mathrm{ijkt}}-\overline{\mathrm{s}}_{\mathrm{jt}}
$$

where $\overline{\mathrm{S}}_{\mathrm{jt}}$ is the median yield spread for all BHCs with BOPEC rating $\mathrm{j}$ at time $\mathrm{t}$ and publicly traded debt. In our empirical work, we found these adjusted yield spreads appear to have more predictive power than the yield spreads based just on the BF indices; hence, $\mathrm{z}_{\text {Dit- } 1}=\mathrm{d}_{\mathrm{ijkt}-1}$.

Note that here we also used the Griliches adjustment for the observations fo which debt prices did not exist. That is, we replaced these missing values with the sample mean of $\mathrm{d}_{\mathrm{ijkt}}$. We also included a fixed effect for this adjustment.

\section{III.B. Empirical results}

We estimate four versions of the BOM model in Equation (1). For the core model containing just supervisory variables, we set $\pi_{\mathrm{E}}=\pi_{\mathrm{D}}=0$. For the equity BOM model, we set $\pi_{\mathrm{D}}=0$, and for the debt BOM model, we set $\pi_{\mathrm{E}}=0$. For the extended BOM model, we do not constrain any of the parameters. The empirical results for the full sample of BOPEC ratings are presented in Tables 5A and 5B. Note that we do not report the coefficients on the interacted supervisory variables for purposes of economizing on space; full tables of results are available upon request.

The coefficients on the securities market variables in the latter three model specifications are statistically significant at conventional levels. The equity market variables have negative signs as expected; i.e., positive values for both systemic and idiosyncratic stock returns tend to be associated with better BHC performance and better (i.e., lower) BOPEC ratings. For the adjusted yield spread variable, the positive sign is also in line with expectations; i.e., higher yield spreads

relative to its corresponding yield index are associated with worse BHC performance and worse (i.e., higher) BOPEC ratings.

The likelihood ratio results indicate that incorporating securities market information 
improves the core BOM model's in-sample fit. The likelihood ratio test statistic for the equity BOM model relative to the core BOM model is 57.0, which has a p-value of $0.0 \%$ under the $\chi^{2}(2)$ distribution. The test statistic for the debt BOM model is 14.2 , which has a p-value of $0.0 \%$ for the $\chi^{2}(1)$ distribution. Finally, the test statistic for the extended BOM model relative to the core model is 100.6 , which has a p-value of $0.0 \%$ under the $\chi^{2}(3)$ distribution.

Clearly, the results indicate that using some type of securities market information within the BOM model is appropriate, but using both equity and debt variables appears to be better than using either one alone. The likelihood ratio test statistic for the extended BOM model relative to the equity BOM model is 49.6 , which has a p-value of $0.0 \%$ for the $\chi^{2}(1)$ distribution. The test statistic for the extended BOM model relative to the debt BOM model is 114.8 , which has a pvalue of $0.0 \%$ for the $\chi^{2}(2)$ distribution. Hence, both sources of market information are shown to be useful complements to the chosen supervisory information set for explaining supervisory BOPEC ratings.

\section{III.C. The relative importance of equity and debt market information}

As noted in the introduction, one of the primary motivations for using both equity and debt market data in a supervisory monitoring model is that no single information source is likely to dominate the other in all states of the world. This insight is confirmed in our empirical results and in the studies cited previously. How then might these two types of market information differ? We might expect that the residual claim feature of equity suggests that equity market investors should be very good at predicting BOPEC rating changes when BHC asset values are relatively far from the default point. In this range for total asset value, changes in value correspond one-to-one with changes in equity values. Debt market investors, by contrast, might be more likely to predict BOPEC rating changes when asset values are relatively close to the default point, as that range for asset values is where changes in values are shared more evenly between stock and bondholders.

As a first pass at these questions, we study events that are consistent with the BHC moving further away from the default point (upgrades), as well as events that imply a BHC is relatively closer to the default point (downgrades). In Tables $6 \mathrm{~A}$ and $6 \mathrm{~B}$, we present the results 
from the estimation of the upgrade and downgrade models. ${ }^{18}$

For upgrades, the SCAR is a significant predictor of a ratings change, while the SCSR is not. The adjusted yield spread also fails to be a significant predictor of BOPEC ratings upgrades. This is consistent with the notion of a bond's payoff being capped. Most of the upgrades in our sample reflect the gradual improvement in banking sector health over the 1990s. From a bondholder's point of view, there may not have been much difference in default probability between a 2-rated and a 1-rated BHC, and spreads did not move much accordingly.

For downgrades, all three sets of financial market variables came in significant. This also is not surprising. If the rating is reflective of overall condition, then that event should be interpreted as a transition to being closer to the default point. Interestingly, both sets of securities market variables have strong statistical significance in the downgrade model. For bondholders, the downgrade is evidently correlated with a decline in credit quality that is priced. For stockholders, the downgrade is correlated with a decline in the residual value of the firm. These basic results carry over when we analyze transitions between the of-concern list (BOPEC 3-5) and the not-of-concern list (BOPEC 1-2).

We can explore the relationship between securities market signals and how close a BHC is to default by explicitly calculating the default point and allowing securities market variables to have differential effects on supervisory ratings, depending on asset values. For this exercise, we use a common model for estimating the value of a firm's asset value. ${ }^{19}$ As per Ronn and Verma (1986), firm asset value is assumed to be a geometric Brownian motion, and the firm's equity can be modeled as a call option on those assets such that,

$$
\mathrm{E}=\mathrm{A} \bullet \mathrm{N}\left(\frac{\ln (\mathrm{A} / \mathrm{D})+\left(\mathrm{s}_{\mathrm{A}}^{2} / 2\right)}{\mathrm{s}_{\mathrm{A}}}\right)-\mathrm{D} \bullet \mathrm{N}\left(\frac{\ln (\mathrm{A} / \mathrm{D})+\left(\mathrm{s}_{\mathrm{A}}^{2} / 2\right)}{\mathrm{s}_{\mathrm{A}}}-\mathrm{s}_{\mathrm{A}}\right),
$$

where $\mathrm{E}$ is the market value of equity, $\mathrm{A}$ is the market value of assets, $\mathrm{D}$ is the book value of

\footnotetext{
${ }^{18}$ Note that the Griliches adjustment and fixed effects described earlier are used here as well.

${ }^{19}$ Gropp et al. (2003) use a similar measure in their study.
} 
debt, $\mathrm{s}_{\mathrm{A}}$ is the standard deviation of changes in asset value, and $\mathrm{N}(\mathrm{x})$ is the standard normal cumulative density function. Since neither the market value of assets nor the volatility are directly observable in the data, a second equation linking $s_{A}$ to equity volatility (denoted as $s_{E}$ ) completes the model; i.e.,

$$
\mathrm{s}_{\mathrm{A}}=\frac{\mathrm{E}}{\mathrm{AN}\left(\frac{\ln (\mathrm{A} / \mathrm{D})+\left(\mathrm{s}_{\mathrm{A}}^{2} / 2\right)}{\mathrm{s}_{\mathrm{A}}}\right)} \mathrm{s}_{\mathrm{E}} \cdot
$$

Essentially, the asset volatility is a de-levered equity volatility. We construct a distance-todefault simply as the difference between $\mathrm{A}$ and $\mathrm{E}$, scaled by $\mathrm{s}_{\mathrm{A}}$.

Working with ordered logit models within the BOM framework, we create indicator variables that take the value one if a BHC's distance-to-default is in a certain percentile of the overall sample distribution of distance-to-default measure. We then interact this indicator variable with the market signals. Since the construction of this indicator variable requires us to restrict the sample to include just BHCs with publicly traded equity, we make the model more parsimonious and include the lagged BOPEC rating as the lone supervisory variable in the model. Formally, the model is,

$$
\mathrm{BP}_{\mathrm{it}}^{*}=\beta \mathrm{BP}_{\mathrm{it}-2}+\left(\pi+\alpha \mathrm{I}_{\mathrm{nit}-1}\right) \mathrm{z}_{\mathrm{it}-1}+\varepsilon_{\mathrm{it}},
$$

where $\mathrm{z}_{\mathrm{it}-1}$ is the securities market variable in question and $\mathrm{I}_{\text {nit- } 1}$ is equal to one if BHC i's distance-to-default is in the $\mathrm{n}^{\text {th }}$ percentile at time $\mathrm{t}-1$, and zero otherwise. ${ }^{20}$

Our main object of interest is whether the coefficients on the securities market variables are different in magnitude depending on how close the BHC is to its default point. The results from this exercise are in Tables 7A and 7B. In Table 7A, the $\mathrm{z}_{\mathrm{it}-1}$ variable is the SCAR variable described previously, and the regressions are based on 1,266 BOPEC ratings for BHCs with publicly traded equity. For this variable, we expect the $\pi$ coefficients to be negative as before, but we expect the $\alpha$ coefficients to be positive. Thus, we expect the stock market signal to be

\footnotetext{
${ }^{20}$ We use the empirical distribution of asset values to identify BHCs "close-to-default." For a large part of our sample, close-to-default compared to one's peers may not correspond to "close-to-default" in the sense that bankruptcy is imminent.
} 
relatively less useful (weaker) for firms close to the default point where changes in asset value also accrue to the bondholders. In Table $7 \mathrm{~B}$, the $\mathrm{z}_{\mathrm{it}-1}$ variable is the adjusted BHC yield spread, and the regressions are based on 282 inspections of firms with publicly traded equity and debt. For this variable, we expect the $\pi$ coefficients to be positive as before. WE expect the $\alpha$ coefficients to be positive as well. The debt market signal should be stronger the closer the BHC is to default.

In Table 7A, we see that our expectations for the SCAR variables are borne out. The coefficient on the SCAR is invariably negative and statistically significant at all but the $90^{\text {th }}$ percentile of the distance-to-default measure. The $\alpha$ coefficients are estimated to be positive for close-to-default cutpoints and decline as the default cut point is increased (although the coefficients on $\alpha$ are never significantly different from zero). Thus, the equity market appears to send a stronger signal when BHCs are further from default based on our definition. Note that the choice of which percentile to use in the definition of the indicator variable $\mathrm{I}_{\text {nit-1 }}$ has no impact on the overall fit of the model.

In Table 7B, we present the results for the relationship between bond market signals and the default point. For BHCs with distance-to-default measures in the bottom $10^{\text {th }}$ percentile of the distribution, the estimated $(\pi+\alpha)$ magnitude of the signal from the bond market is more than four times as large as when a BHC is further from default. Indeed, for higher percentiles of the distance-to-default distribution, the $\alpha$ coefficients are never statistically significant. As in Table $7 \mathrm{~A}$, the choice of which percentile to use in defining the indicator variable has no impact on the overall fit of the model.

In summary, our simplified ordered logit models suggest an asymmetric contribution of equity and debt market signals to explaining BOPEC ratings, and the asymmetry depends on how close the BHC is to its default point. The coefficients on the equity market signals are largest in magnitude for the case of BHCs defined to be far from default, while the coefficients on the adjusted yield spreads are much larger in magnitude for BHCs defined to be very close to default. The fact that the adjusted yield spreads are significant predictors of the BOPEC rating when the close-to-default definition is very strict suggests that, for most of our sample, it was rare for BHCs with publicly traded debt to be very close to the default point in absolute terms. 


\section{III.D. Out-of-sample performance}

Although the BOM model's in-sample fit and inference is interesting and important, a stricter test of its usefulness for supervisory purposes is whether it has predictive power out of sample. As in Krainer and Lopez (2003a,b), we evaluate the forecasting ability of the models described above by estimating them over rolling, four-quarter sample periods and compare their predicted BOPEC ratings to the realized ones. Clearly, the number of BOPEC ratings assigned with these subsamples will be small relative to the full sample, but we accept the smaller sample sizes in order to simulate how securities market data might be used in practice by supervisors.

Our measure of whether a model forecasts well is to ask how often its forecasts are correct. For example, if the model generates a signal suggesting an upgrade, what percentage of the time does an upgrade actually take place? The upgrade and downgrade forecasts from the models are based on forecasted ratings that are a full rating better or worse than the previously assigned rating. As shown in Table 8A, for the core model, an upgrade signal received four quarter prior to inspection materializes into an actual upgrade $55 \%$ of the time; $36 \%$ of the time the actual outcome of the inspection is no change in rating; and $9 \%$ of the time the actual outcome is a downgrade. By one quarter prior to the inspection, the upgrade signal is accurate $90 \%$ of the time. The model appears to be just as effective at picking up downgrades. Four quarters prior to the inspection, a downgrade signal is accurate $68 \%$ of the time, improving to $91 \%$ accuracy one quarter prior to the inspection.

In the full sample, the unconditional probabilities of upgrades, downgrades, and no change at the inspection are $22 \%, 12 \%$, and $66 \%$, respectively. Thus, the conditioning supervisory information in the core model is clearly useful relative to these unconditional probabilities. This notion is formalized by the Pearson goodness-of-fit results in the right-most column, which test whether the conditional probabilities generated by the model are statistically different from the unconditional probabilities. We easily reject the null hypothesis that the conditioning variables do not provide useful information for forecasting BOPEC ratings.

As shown in Tables 8B through 8D, model accuracy is little changed after incorporating securities market data, and in many cases is a little bit worse. With respect to the equity BOM model, the results in Table $8 \mathrm{~B}$ show that signal accuracy increases from $62 \%$ four quarters prior 
to inspection to $91 \%$ accuracy within one quarter of the inspection, compared to $55 \%$ and $90 \%$, respectively, for the core model. However, for downgrades, forecast accuracy improves from $56 \%$ to $82 \%$ as the inspection approaches, not quite as large an improvement as observed for the core model. Overall, the Pearson test suggests that the addition of the two equity market variables does not improve forecast accuracy significantly. In fact, at both four and one quarter prior, these variables reduce forecast accuracy.

In Table 8C, the debt BOM model's forecasting accuracy is actually a little worse than the accuracy of the core model with only supervisory variables. An upgrade signal four quarters prior to the inspection is correct $62 \%$ of the time, while a downgrade signal at four quarters prior results in an actual downgrade $56 \%$ of the time. When compared to the core model's forecasts using the Pearson test, we cannot reject the null hypothesis that the debt market variables do not improve forecast accuracy. The two model's forecasts are shown to be different at two and one quarter prior because the debt BOM model performs worse.

Finally, as shown in Table 8D, the forecast accuracy of the extended model with both equity and debt market variables is nearly indistinguishable from the accuracy of the core model

at all horizons. In summary, the forecasting accuracy of the extended models looks very similar. The inclusion of securities market variables in the core BOM model fails to improve overall BOPEC forecast accuracy at conventional levels of significance.

\section{III.E. Information in the Forecasts}

Although BOPEC rating forecasts do not appear to be appreciably different across the core and the extended BOM models, BOPEC rating changes correctly forecasted by the two models are not identical. The forecasting literature has shown that combining forecasts from different models can improve certain aspects of forecast accuracy. That appears to be possible in our case, since the models signal BOPEC changes for different, although overlapping, sets of BHCs. Hence, another way to gauge the contribution of securities market information is to examine the additional forecast signals for public BHCs as generated by the extended models relative to the core model's signals. Seen in this light, the marginal benefit of adding these additional signals to those from the core model is notable. 
Comparing signals generated by the core and the three extended models, we ask what is the percentage increase in the number of correct signals when securities market data are incorporated into the core BOM model? All of these additional correct forecasts are for ratings changes at BHCs with publicly traded securities. As reported in Table 9A, the extended model with adjusted bond yields and stock return data produces $22 \%$ more correct signals at the four quarter horizon over and above those produced by the core model. At the one quarter horizon, the improvement is $25 \%$ more signals. Another interesting point in Table $9 \mathrm{~A}$ is the similarity between the marginal contributions of the equity BOM model and the debt and equity BOM model. Evidently, in this particular framework, most of the additional downgrade signals a supervisor can extract from securities market data come from the equity market. This result contrasts with the in-sample results and may be due to the relatively small number of BHCs with publicly traded debt in any given subsample period.

Of course, the extended models produce incorrect signals over and above those produced by the core model. Given that Table 9A shows that the extended models help identify additional BOPEC downgrades, these mistakes may be responsible for our earlier result that the forecast accuracy of the core and extended models are almost the same. We examine this tradeoff more closely in Table 9B, where we express the models' ratios of correct downgrade signals to incorrect signals. For example, in the case of the extended BOM model at the four quarter horizon, the model produces 11 additional correct signal at the cost of 25 incorrect downgrade signals. By the one quarter horizon, however, the accuracy improves dramatically to five additional correct signals at the cost of only three additional incorrect signals. The models extended by equity variables and debt variables alone behave quite similarly. Interestingly, this signal tradeoff for the debt BOM model extended with debt market information is quite good; by one quarter out, it produces five correct signals for every incorrect signal. However, as indicated in Table 9A, the drawback to this model is that it produces relatively fewer signals beyond those from the core model.

\section{Conclusion}

In conclusion, our empirical results indicate that both equity and debt market information 
are useful in improving the in-sample fit of our proposed BOM model for BOPEC ratings. Both types of securities market information appear to be useful in explaining BOPEC upgrades and downgrades. Moreover, we detect nonlinearities in the impact of financial market variables on BOPEC ratings. Close to default, the estimated effect of our adjusted bond yield spreads on BOPEC ratings is larger in magnitude than it is for BHCs far from default, and vice-versa for equity market data.

When we turn to out-of-sample forecasting, evidence for the usefulness of market information is disappointingly weak. We estimate our four BOM model specifications on a rolling subsample of data and then forecast BOPEC ratings out-of-sample. We find the forecast accuracy of the three models that include securities market data is not much different than the accuracy of the core model based on supervisory data alone.

However, while the out-of-sample forecasting accuracy of the core and extended models is similar, we note that the actual forecasts are quite different. That is, the core model correctly identifies one set of BOPEC rating changes, while the extended models correctly identify other sets of rating changes. We find that the extended models correctly identify additional ratings changes for publicly traded BHCs over and above the correct forecasts in the core model. These additional correct forecasts can be achieved at a relatively modest cost of additional incorrect signals. Hence, supervisory use of securities market information within the context of an off-site monitoring model, such as our proposed BOM model, appears to be reasonable. 


\section{References}

Basel Committee on Banking Supervision, 2003. "Markets for Bank Subordinated Debt and Equity in Basel Committee Member Countries," Working Paper \#12, Bank for International Settlements.

Basel Committee on Banking Supervision, 2001. "The New Basel Accord." Consultative Paper, Bank for International Settlements. (http://www.bis.org/publ/bcbsca.htm)

Basel Committee on Banking Supervision, 2003. "Markets for Bank Subordinated Debt and Equity in Basel Committee Member Countries," Working paper \#12, Bank for International Settlements.

Berger, A. N., and Davies, S. M., 1998. "The Information Content of Bank Examinations," Journal of Financial Services Research, 14, 117-144.

Berger, A.N., Davies, S.M., and Flannery, M.J., 2000. "Comparing Market and Supervisory Assessments of Bank Performance: Who Knows What When?," Journal of Money, Credit and Banking, 32, 641-667.

Bliss, R., 2000. "The Pitfalls in Inferring Risk from Financial Market Data," Manuscript, Economic Research Department, Federal Reserve Bank of Chicago.

Bliss, R. and Flannery, M., 2001. "Market Discipline in the Governance of U.S. Bank Holding Companies: Monitoring versus Influence," pages 107-143, in R. Mishkin, ed., Prudential Supervision: Why Is It Important and What are the Issues?. National Bureau of Economic Research.

Board of Governors of the Federal Reserve System, 1999. "Using Subordinated Debt as an Instrument of Market Discipline: Report of the Study Group on Subordinated Notes and Debentures," Federal Reserve System Staff Study \# 172.

Board of Governors of the Federal Reserve System and the U.S. Department of the Treasury, 2000. "The Feasibility and Desirability of Mandatory Subordinated Debt," Report to Congress pursuant to section 108 of the Gramm-Leach-Bliley Act of 1999.

Campbell, J., Lo, A., and MacKinlay, A., 1997. The Econometrics of Financial Markets. Princeton University Press.

Cannata, F. and Quagliariello, M., 2003. "Market and Supervisory Information: Some Evidence from Italian Banks," Manuscript, Banking and Financial Supervision, Banca d'Italia.

Cole, R.A. and Gunther, J.W., 1998. "Predicting Bank Failures: A Comparison of On- and 
Off-Site Monitoring Systems," Journal of Financial Services Research, 13, 103-17.

Covitz, D.M., Hancock, D. and Kwast, M.L., 2002. "Market Discipline in Banking Reconsidered: The Roles of Deposit Insurance Reform, Funding Manager Decisions and Bond Market Liquidity," Finance and Economics Discussion Series \#2002-46, Board of Governors of the Federal Reserve System.

Curry, T., Fissel, G. and Hanweck, G., 2003. "Market Information, Bank Holding Company Risk and Market Discipline," Manuscript, Division of Insurance and Research, Federal Deposit Insurance Corporation.

Curry, T.J., Elmer, P.J. and Fissel, G., 2001. "Regulator Use of Market-Related Data to Improve the Identification of Bank Financial Health," Manuscript, Federal Deposit Insurance Corporation.

DeFerrari, L, and Palmer, D., 2001. "Supervision of Large Complex Banking Organizations." Federal Reserve Bulletin, February, 47-57.

DeYoung, R., Flannery, M., Lang, M., and Sorescu, S., 2001. "The Information Content Bank Exam Ratings and Subordinated Debt Prices," Journal of Money, Credit, and Banking, 33, 900-925.

Elmer, P.J. and Fissel, G., 2001. "Forecasting Bank Failure from Momentum Patterns in Stock Returns," Manuscript, Federal Deposit Insurance Corporation.

Estrella, A., Park, S. and Peristiani, S., 2000. "Capital Ratios as Predictors of Bank Failure", Federal Reserve Bank of New York Economic Policy Review, July, 33-52.

Evanoff, D., and Wall, L., 2001. "Sub-Debt Yield Spreads as Bank Risk Measures," Journal of Financial Services Research, 20, 121-146.

Evanoff, D., and Wall, L., 2002. "Measures of the Riskiness of Banking Organizations: Subordinated Debt Yields, Risk-Based Capital and Examination Ratings," Journal of Banking and Finance, 26, 989-1009.

Flannery, M., 1998. "Using Market Information in Prudential Bank Supervision," Journal of Money, Credit, and Banking, August, Part I, 273-305.

Flannery, M., Kwan, S., and Nimalendran, M., 2003. "Market Evidence on the Opaqueness of Banking Firms' Assets," Journal of Financial Economics, forthcoming.

Flannery, M., and Sorescu, S., 1996. "Evidence of Bank Market Discipline in Subordinated Debenture Yields: 1983-1991," Journal of Finance, 51, 1347-1377. 
González-Rivera, G. and Nickerson, D., 2003. "Monitoring Financial Intermediaries with Subordinated Debt: A Dynamic Signal Model for Bank Risk," Manuscript, Department of Economics, University of California, Riverside.

Goyal, V.K., 1998. "Market Discipline of Bank Risk: Evidence from Subordinated Debt Contracts," Manuscript, Department of Finance, Hong Kong University of Science and Technology.

Griliches, Z., 1986. "Economic Data Issues," in Griliches, Z. and Intriligator, M.D., eds., Handbook of Econometrics, Volume III. Elsevier Science Publishers BV.

Gropp, R. and Richards, A.J., 2001. "Rating Agencies and the Pricing of Debt and Equity of European Banks: What Can We Infer About Private Sector Monitoring of Bank Soundness?," Working paper \#76, European Central Bank.

Gropp, R., Vesala, J. and Vulpes, G., 2003. "Equity and Bond Market Signals as Leading Indicators of Bank Fragility," Working paper \#150, European Central Bank.

Gunther, J.W., Levonian, M.E. and Moore, R.R., 2001. "Can the Stock Market Tell Bank Supervisors Anything They Don't Already Know?," Federal Reserve Bank of Dallas Economic and Financial Review, Second Quarter, 2-9.

Gunther, J.W. and Moore, R.R., 2003. "Early Warning Models in Real Time,” Journal of Banking and Finance, 27, 1979-2002.

Hall, J.R., King, T.B., Meyer, A.P. and Vaughn, M.D., 2001. "What Can Bank Supervisors Learn from the Equity Markets? A Comparison of the Factors Affecting Market-Based Risk Measures and BOPEC Scores," Manuscript, Federal Reserve Bank of St. Louis.

Hancock, D., and Kwast, M., 2001. "Using Subordinated Debt to Monitor Bank Holding Companies: Is it Feasible?," Journal of Financial Services Research, 20, 147-187.

Hirtle, B. and Lopez, J.A., 1999. "Supervisory Information and the Frequency of Bank Examinations," Federal Reserve Bank of New York Economic Policy Review, April, 1-20.

Karafiath, I., Mynatt, R. and Smith, K.L., 1991. "The Brazilian Default Announcement and the Contagion Effect Hypothesis," Journal of Banking and Finance, 15, 699-716.

Krainer, J. and Lopez, J.A., 2003a. "What Role Can Securities Market Information Play in the Supervisory Monitoring Process?," Federal Reserve Bank of San Francisco Economic Review, 29-45.

Krainer, J. and Lopez, J.A., 2003b. "Incorporating Equity Market Information into Supervisory 
Monitoring Models," Journal of Money, Credit and Banking, forthcoming.

Meyer, P. and Pifer, H., 1970. "Prediction of Bank Failures," Journal of Finance, 25, 853-868.

Morgan, D.P., 2002. "Rating Banks: Risk and Uncertainty," American Economic Review, 92, 874-888.

Pettway, R.H., 1976. "Market Tests of Capital Adequacy of Large Commercial Banks," Journal of Finance, 31, 865-875.

Pettway, R.H. and Sinkey, J.F., 1980. "Establishing On-Site Bank Examination Priorities: An Early-Warning System using Accounting and Market Information," Journal of Finance, $35,137-150$.

Ronn, E.I. and Verma, A.K., 1986. "Pricing Risk-Adjusted Deposit Insurance: An Option-Based Model," Journal of Finance, 41, 871-895.

Sinkey, J.E., 1975. "A Multivariate Statistical Analysis of the Characteristics of Problem Banks," Journal of Finance, 20, 21-36.

Sahajwala, R. and Van der Bergh, P., 2000. "Supervisory Risk Assessment and Early Warning Systems," Basel Committee on Banking Supervision Working Paper No. 4, Bank for International Settlements.

Shick, R.A. and Sherman, L.F., 1980. "Bank Stock Prices as an Early Warning System for Changes in Condition," Journal of Banking Research, 11, 136-146. 
Table 1. Asset size characteristics of the BHCs in the BOPEC sample

\begin{tabular}{|c|c|c|c|}
\hline & 1990-1998 & 1990-1994 & 1995-1998 \\
\hline Total \# ratings & 3,010 & 1,735 & 1,275 \\
\hline $\begin{array}{l}\text { Asset size: } \\
\quad \text { Assets }>\$ 100 \mathrm{~b}\end{array}$ & 41 & 13 & 28 \\
\hline$\$ 1 \mathrm{~b}<$ Assets $<\$ 100 \mathrm{~b}$ & 1,019 & 594 & 425 \\
\hline Assets $<\$ 1 b$ & 1,950 & 1,128 & 822 \\
\hline Total \# ratings, public BHCs & 1,291 & 741 & 550 \\
\hline $\begin{array}{l}\text { Asset size: } \\
\quad \text { Assets }>\$ 100 \mathrm{~b}\end{array}$ & 39 & 13 & 26 \\
\hline$\$ 1 \mathrm{~b}<$ Assets $<\$ 100 \mathrm{~b}$ & 807 & 487 & 320 \\
\hline Assets $<\$ 1 \mathrm{~b}$ & 445 & 241 & 204 \\
\hline $\begin{array}{l}\text { Total \# ratings, BHCs with } \\
\text { public debt }\end{array}$ & 309 & 174 & 135 \\
\hline $\begin{array}{l}\text { Asset size: } \\
\text { Assets }>\$ 100 \mathrm{~b}\end{array}$ & 37 & 11 & 26 \\
\hline$\$ 1 \mathrm{~b}<$ Assets $<\$ 100 \mathrm{~b}$ & 270 & 163 & 107 \\
\hline Assets $<\$ 1 \mathrm{~b}$ & 2 & 0 & 2 \\
\hline $\begin{array}{c}\text { Total \# ratings, public BHCs } \\
\text { with public debt }\end{array}$ & 283 & 163 & 120 \\
\hline $\begin{array}{l}\text { Asset size: } \\
\quad \text { Assets > } \$ 100 \mathrm{~b}\end{array}$ & 36 & 11 & 25 \\
\hline$\$ 1 \mathrm{~b}<$ Assets $<\$ 100 \mathrm{~b}$ & 247 & 152 & 95 \\
\hline Assets $<\$ 1 \mathrm{~b}$ & 0 & 0 & 0 \\
\hline
\end{tabular}

Note: The data sample spans the period from the beginning of 1990 to the second quarter of 1998. The definition of a bank holding company (BHC) used in this table is the definition used in constructing our dataset; i.e., a top-tier BHC with an identifiable lead bank, four quarters of available regulatory reporting data and a lagged BOPEC rating. Public debt here refers to publicly-traded bonds as listed in the Warga/Lehmann dataset and as per Bliss and Flannery (2001). 
Table 2A. All BOPEC ratings in the sample

\begin{tabular}{r|rrrr} 
& \multicolumn{5}{|c}{ BOPEC Rating \% of total } \\
\hline & 1 & 2 & 3 & $4-5$ \\
\hline 1990 & $16 \%$ & $52 \%$ & $21 \%$ & $10 \%$ \\
1991 & $16 \%$ & $47 \%$ & $25 \%$ & $12 \%$ \\
1992 & $15 \%$ & $52 \%$ & $20 \%$ & $14 \%$ \\
1993 & $24 \%$ & $55 \%$ & $14 \%$ & $7 \%$ \\
1994 & $34 \%$ & $53 \%$ & $8 \%$ & $5 \%$ \\
1995 & $36 \%$ & $52 \%$ & $8 \%$ & $5 \%$ \\
1996 & $47 \%$ & $47 \%$ & $5 \%$ & $1 \%$ \\
1997 & $47 \%$ & $48 \%$ & $4 \%$ & $0 \%$ \\
1998 & $47 \%$ & $49 \%$ & $3 \%$ & $0 \%$ \\
\hline Total & $31 \%$ & $51 \%$ & $12 \%$ & $6 \%$
\end{tabular}

Note: The data sample spans the period from the beginning of 1990 to the second quarter of 1998.

\section{Table 2B. All BOPEC ratings for the publicly traded BHCs in the sample}

\begin{tabular}{r|rrrr} 
& \multicolumn{4}{|c}{ BOPEC rating \% of total } \\
\hline & 1 & 2 & 3 & $4-5$ \\
\hline 1990 & $17 \%$ & $58 \%$ & $14 \%$ & $8 \%$ \\
1991 & $17 \%$ & $48 \%$ & $24 \%$ & $11 \%$ \\
1992 & $28 \%$ & $46 \%$ & $17 \%$ & $14 \%$ \\
1993 & $30 \%$ & $51 \%$ & $12 \%$ & $7 \%$ \\
1994 & $38 \%$ & $50 \%$ & $7 \%$ & $5 \%$ \\
1995 & $35 \%$ & $53 \%$ & $8 \%$ & $3 \%$ \\
1996 & $48 \%$ & $49 \%$ & $3 \%$ & $0 \%$ \\
1997 & $48 \%$ & $50 \%$ & $1 \%$ & $1 \%$ \\
1998 & $49 \%$ & $51 \%$ & $0 \%$ & $0 \%$ \\
\hline Total & $34 \%$ & $51 \%$ & $10 \%$ & $6 \%$
\end{tabular}

Note: The data sample spans the period from the beginning of 1990 to the second quarter of 1998. 
Table 2C. All BOPEC ratings for the BHCs with publicly traded bonds in the sample

\begin{tabular}{r|rrrr} 
& \multicolumn{5}{|c}{ BOPEC Rating \% of total } \\
\hline & 1 & 2 & 3 & $4-5$ \\
\hline 1990 & $19 \%$ & $55 \%$ & $16 \%$ & $10 \%$ \\
1991 & $11 \%$ & $36 \%$ & $32 \%$ & $21 \%$ \\
1992 & $17 \%$ & $42 \%$ & $25 \%$ & $17 \%$ \\
1993 & $22 \%$ & $69 \%$ & $3 \%$ & $6 \%$ \\
1994 & $41 \%$ & $54 \%$ & $5 \%$ & $0 \%$ \\
1995 & $41 \%$ & $59 \%$ & $0 \%$ & $0 \%$ \\
1996 & $58 \%$ & $42 \%$ & $0 \%$ & $0 \%$ \\
1997 & $54 \%$ & $46 \%$ & $0 \%$ & $0 \%$ \\
1998 & $62 \%$ & $38 \%$ & $0 \%$ & $0 \%$ \\
\hline Total & $36 \%$ & $50 \%$ & $0 \%$ & $6 \%$
\end{tabular}

Note: The data sample spans the period from the beginning of 1990 to the second quarter of 1998.

Table 2D. All BOPEC ratings for BHCs with public equity and bonds in the sample

\begin{tabular}{r|rrrr} 
& \multicolumn{4}{|c}{ BOPEC Rating \% of total } \\
\hline & 1 & 2 & 3 & $4-5$ \\
\hline 1990 & $21 \%$ & $55 \%$ & $17 \%$ & $7 \%$ \\
1991 & $12 \%$ & $35 \%$ & $31 \%$ & $23 \%$ \\
1992 & $18 \%$ & $41 \%$ & $26 \%$ & $15 \%$ \\
1993 & $24 \%$ & $68 \%$ & $3 \%$ & $6 \%$ \\
1994 & $45 \%$ & $50 \%$ & $5 \%$ & $0 \%$ \\
1995 & $44 \%$ & $56 \%$ & $0 \%$ & $0 \%$ \\
1996 & $60 \%$ & $40 \%$ & $0 \%$ & $0 \%$ \\
1997 & $58 \%$ & $42 \%$ & $0 \%$ & $0 \%$ \\
1998 & $68 \%$ & $32 \%$ & $0 \%$ & $0 \%$ \\
\hline Total & $38 \%$ & $48 \%$ & $9 \%$ & $5 \%$
\end{tabular}

Note: The data sample spans the period from the beginning of 1990 to the second quarter of 1998. 
Table 3A. All BOPEC rating changes in the sample

\begin{tabular}{r|rrrr|rrr} 
& \multicolumn{5}{|l|}{ Change in BOPEC rating } & & $\%$ of total \\
& Upgrade & No change Downgrade & Total & Upgrade & No change & Downgrade \\
\hline 1990 & 21 & 184 & 57 & 262 & $8 \%$ & $70 \%$ & $22 \%$ \\
1991 & 33 & 172 & 93 & 300 & $11 \%$ & $57 \%$ & $31 \%$ \\
1992 & 73 & 231 & 72 & 376 & $19 \%$ & $61 \%$ & $19 \%$ \\
1993 & 111 & 265 & 20 & 396 & $28 \%$ & $67 \%$ & $5 \%$ \\
1994 & 107 & 263 & 31 & 401 & $27 \%$ & $66 \%$ & $8 \%$ \\
1995 & 113 & 260 & 29 & 402 & $28 \%$ & $65 \%$ & $7 \%$ \\
1996 & 102 & 289 & 22 & 413 & $25 \%$ & $70 \%$ & $5 \%$ \\
1997 & 85 & 264 & 22 & 371 & $23 \%$ & $71 \%$ & $6 \%$ \\
1998 & 13 & 73 & 3 & 89 & $15 \%$ & $82 \%$ & $3 \%$ \\
\hline Total & 660 & 2,001 & 349 & 3,010 & $22 \%$ & $66 \%$ & $12 \%$
\end{tabular}

Note: The data sample spans the period from the beginning of 1990 to the second quarter of 1998.

Table 3B. All BOPEC rating changes for the publicly traded BHCs in the sample

\begin{tabular}{r|rrrr|rrr} 
& Change in BOPEC rating & & $\%$ of total & & \\
\hline & Upgrade & No change Downgrade & Total & Upgrade & No change & Downgrade \\
\hline 1990 & 8 & 76 & 34 & 118 & $7 \%$ & $64 \%$ & $29 \%$ \\
1991 & 8 & 79 & 40 & 127 & $6 \%$ & $62 \%$ & $31 \%$ \\
1992 & 28 & 98 & 28 & 154 & $18 \%$ & $64 \%$ & $18 \%$ \\
1993 & 53 & 105 & 8 & 166 & $32 \%$ & $63 \%$ & $5 \%$ \\
1994 & 43 & 121 & 12 & 176 & $24 \%$ & $69 \%$ & $7 \%$ \\
1995 & 48 & 118 & 15 & 181 & $27 \%$ & $65 \%$ & $8 \%$ \\
1996 & 40 & 124 & 11 & 175 & $23 \%$ & $71 \%$ & $6 \%$ \\
1997 & 26 & 109 & 8 & 143 & $18 \%$ & $76 \%$ & $6 \%$ \\
1998 & 7 & 43 & 1 & 51 & $14 \%$ & $84 \%$ & $2 \%$ \\
\hline Total & 261 & 873 & 157 & 1,291 & $20 \%$ & $68 \%$ & $12 \%$
\end{tabular}

Note: The data sample spans the period from the beginning of 1990 to the second quarter of 1998. 
Table 3C. All BOPEC rating changes for the BHCs holding debt in the sample

\begin{tabular}{|c|c|c|c|c|c|c|c|}
\hline & \multicolumn{4}{|c|}{ Change in BOPEC rating } & \multicolumn{3}{|l|}{$\%$ of total } \\
\hline & Upgrade & No change & Downgrade & Total & Upgrade & No change & Downgrade \\
\hline 1990 & 3 & 20 & 8 & 31 & $10 \%$ & $65 \%$ & $26 \%$ \\
\hline 1991 & 3 & 15 & 10 & 28 & $11 \%$ & $54 \%$ & $36 \%$ \\
\hline 1992 & 3 & 28 & 5 & 36 & $8 \%$ & $78 \%$ & $14 \%$ \\
\hline 1993 & 16 & 20 & 0 & 36 & $44 \%$ & $56 \%$ & $0 \%$ \\
\hline 1994 & 7 & 34 & 0 & 41 & $17 \%$ & $83 \%$ & $0 \%$ \\
\hline 1995 & 6 & 33 & 2 & 41 & $15 \%$ & $80 \%$ & $5 \%$ \\
\hline 1996 & 7 & 28 & 1 & 36 & $19 \%$ & $78 \%$ & $3 \%$ \\
\hline 1997 & 4 & 29 & 2 & 35 & $11 \%$ & $83 \%$ & $6 \%$ \\
\hline 1998 & 3 & 17 & 1 & 21 & $14 \%$ & $81 \%$ & $5 \%$ \\
\hline Total & 52 & 224 & 29 & 305 & $17 \%$ & $73 \%$ & $10 \%$ \\
\hline
\end{tabular}

Note: The data sample spans the period from the beginning of 1990 to the second quarter of 1998.

Table 3D. All BOPEC ratings for BHCs with public equity and bonds in the sample

\begin{tabular}{r|rrrr|rrr|} 
& Change in BOPEC rating & & \% of total & & \\
\hline & Upgrade & No change Downgrade & Total & Upgrade & No change & Downgrade \\
\hline 1990 & 3 & 19 & 7 & 29 & $10 \%$ & $66 \%$ & $24 \%$ \\
1991 & 2 & 15 & 9 & 26 & $8 \%$ & $58 \%$ & $35 \%$ \\
1992 & 3 & 27 & 4 & 34 & $9 \%$ & $79 \%$ & $12 \%$ \\
1993 & 15 & 19 & 0 & 34 & $44 \%$ & $56 \%$ & $0 \%$ \\
1994 & 7 & 31 & 0 & 38 & $18 \%$ & $82 \%$ & $0 \%$ \\
1995 & 6 & 28 & 2 & 36 & $17 \%$ & $78 \%$ & $6 \%$ \\
1996 & 6 & 23 & 1 & 30 & $21 \%$ & $77 \%$ & $3 \%$ \\
1997 & 4 & 27 & 2 & 33 & $12 \%$ & $82 \%$ & $6 \%$ \\
1998 & 3 & 15 & 1 & 19 & $16 \%$ & $79 \%$ & $5 \%$ \\
\hline Total & 49 & 204 & 26 & 279 & $18 \%$ & $73 \%$ & $9 \%$
\end{tabular}

Note: The data sample spans the period from the beginning of 1990 to the second quarter of 1998. 
Table 4. Summary Statistics for Financial Statement and Supervisory Variables

\begin{tabular}{l|lllll} 
& Mean & Std. Dev. & 25 pctile & Median & 75 pctile \\
\hline Assets (\$m) & $\$ 6,336$ & $\$ 23,700$ & $\$ 250$ & $\$ 493$ & $\$ 2,068$ \\
CAMELS rating & 1.94 & 0.80 & 1 & 2 & 3 \\
$\begin{array}{l}\text { Nonperforming } \\
\text { loans / assets }\end{array}$ & $1.97 \%$ & $1.87 \%$ & $0.87 \%$ & $1.47 \%$ & $2.41 \%$ \\
$\begin{array}{l}\text { Allowances for } \\
\text { loan losses / } \\
\text { assets }\end{array}$ & $0.41 \%$ & $0.69 \%$ & $0.09 \%$ & $0.21 \%$ & $0.44 \%$ \\
$\begin{array}{l}\text { Section 20 } \\
\text { subsidiary }\end{array}$ & 0.04 & & & & \\
$\begin{array}{l}\text { Trading assets / } \\
\text { assets }\end{array}$ & $1.10 \%$ & 0.19 & 0.00 & 0.00 & 0.00 \\
$\begin{array}{l}\text { Double leverage } \\
\text { Return on }\end{array}$ & $55.24 \%$ & $108.34 \%$ & $7.29 \%$ & $43.27 \%$ & $98.21 \%$ \\
$\begin{array}{l}\text { average assets } \\
\text { Equity capital / } \\
\text { assets }\end{array}$ & $0.82 \%$ & $0.97 \%$ & $0.66 \%$ & $0.98 \%$ & $1.22 \%$ \\
& $8.18 \%$ & $2.47 \%$ & $6.71 \%$ & $7.88 \%$ & $9.26 \%$ \\
& & & & & \\
\end{tabular}


Table 5A. BOM Model Estimation Results

\begin{tabular}{|c|c|c|c|c|}
\hline & \multicolumn{2}{|c|}{ Core BOM model } & \multicolumn{2}{|c|}{ Equity BOM model } \\
\hline & coefficients & p-value & coefficients & p-value \\
\hline lagged BOPEC & 1.292 & 0.00 & 1.363 & 0.00 \\
\hline CAMELS & 1.223 & 0.00 & 1.266 & 0.00 \\
\hline Total assets & -0.247 & 0.00 & -0.160 & 0.03 \\
\hline Problem loans & 48.050 & 0.00 & 48.837 & 0.00 \\
\hline Allowances & 56.676 & 0.00 & 57.266 & 0.00 \\
\hline Trading assets & 0.004 & 0.49 & 0.008 & 0.19 \\
\hline Section 20 sub. & 1.819 & 0.00 & 2.203 & 0.00 \\
\hline Double leverage & 0.054 & 0.25 & 0.059 & 0.16 \\
\hline $\mathrm{ROA}$ & -1.015 & 0.00 & -1.000 & 0.00 \\
\hline Equity capital & -22.103 & 0.00 & -21.446 & 0.00 \\
\hline SCSR & - & - & -0.828 & 0.00 \\
\hline SCAR & - & - & -0.529 & 0.00 \\
\hline Adj. yield spread & - & - & - & - \\
\hline Observations & 3,010 & & 3,010 & \\
\hline Log likelihood & $-1,843.1$ & & $-1,814.6$ & \\
\hline $\begin{array}{l}\text { Likelihood ratio } \\
\text { test }\end{array}$ & & & 57.0 & \\
\hline pseudo $\mathrm{R}^{2}$ & 0.47 & & 0.48 & \\
\hline
\end{tabular}

Note: The models estimated here are summarized in Equation 1. The results for the interacted supervisory variables and fixed effects are not reported to conserve space. The models contained fixed effects for BHCs with public equity, BHCs with public equity for which SCAR and SCSR variables could not be properly calculated, and BHCs with pubic debt. The sample period ranges is 1990.Q1 to 1998.Q2. The model was estimated using robust standard errors and adjusting for clustered observations based on unique BHCs. The likelihood ratio tests the null hypothesis that the coefficients on the financial market variables in the extended models are zero. 
Table 5B. BOM Model Estimation Results

\begin{tabular}{|c|c|c|c|c|}
\hline & \multicolumn{2}{|c|}{ Debt BOM model } & \multicolumn{2}{|c|}{ Extended BOM model } \\
\hline & coefficients & p-value & coefficients & p-value \\
\hline lagged BOPEC & 1.338 & 0.00 & 1.375 & 0.00 \\
\hline CAMELS & 1.104 & 0.00 & 1.288 & 0.00 \\
\hline Total assets & -0.133 & 0.00 & -0.170 & 0.02 \\
\hline Problem loans & 46.118 & 0.00 & 49.724 & 0.00 \\
\hline Allowances & 70.663 & 0.00 & 59.337 & 0.00 \\
\hline Trading assets & -0.002 & 0.77 & 0.008 & 0.20 \\
\hline Section 20 sub. & -0.198 & 0.68 & 1.280 & 0.05 \\
\hline Double leverage & 0.041 & 0.69 & 0.063 & 0.13 \\
\hline $\mathrm{ROA}$ & -0.930 & 0.00 & -1.000 & 0.00 \\
\hline Equity capital & -25.712 & 0.00 & -21.506 & 0.00 \\
\hline SCSR & - & - & -0.804 & 0.00 \\
\hline SCAR & - & - & -0.522 & 0.00 \\
\hline Adj. yield spread & 2.387 & 0.00 & 2.234 & 0.00 \\
\hline Observations & 3,010 & & 3,010 & \\
\hline Log likelihood & $-1,850.2$ & & $-1,792.8$ & \\
\hline $\begin{array}{l}\text { Likelihood ratio } \\
\text { test }\end{array}$ & 14.2 & & 100.6 & \\
\hline pseudo $\mathrm{R}^{2}$ & 0.48 & & 0.49 & \\
\hline
\end{tabular}

Note: The models estimated here are summarized in Equation 1. The results for the interacted supervisory variables and fixed effects are not reported to conserve space. The models contained fixed effects for BHCs with public equity, BHCs with public equity for which SCAR and SCSR variables could not be properly calculated, and BHCs with pubic debt. The sample period ranges is 1990.Q1 to 1998.Q2. The model was estimated using robust standard errors and adjusting for clustered observations based on unique BHCs. The likelihood ratio tests the null hypothesis that the coefficients on the financial market variables in the extended models are zero. 
Table 6A. Upgrade and Downgrade Model Estimation Results

\begin{tabular}{|c|c|c|c|c|}
\hline & \multicolumn{2}{|c|}{ Upgrade model } & \multicolumn{2}{|c|}{ Downgrade model } \\
\hline & coefficient & p-value & $\underline{\text { coefficient }}$ & p-value \\
\hline Lagged BOPEC & 4.794 & 0.00 & -3.061 & 0.00 \\
\hline CAMELS & -0.867 & 0.00 & 1.138 & 0.00 \\
\hline $\ln$ (assets) & 0.137 & 0.37 & -0.327 & 0.00 \\
\hline Problem loans & -53.508 & 0.00 & 44.664 & 0.00 \\
\hline Allowances & -87.882 & 0.02 & 57.887 & 0.01 \\
\hline Section 20 & -10.391 & 0.00 & 0.350 & 0.724 \\
\hline Trading assets & -16.494 & 0.81 & -0.391 & 0.85 \\
\hline Double Leverage & -0.101 & 0.00 & -0.079 & 0.69 \\
\hline ROA & 1.181 & 0.01 & -0.510 & 0.06 \\
\hline Equity capital & 12.008 & 0.04 & -14.110 & 0.05 \\
\hline SCSR & 0.143 & 0.73 & -1.011 & 0.00 \\
\hline SCAR & 0.515 & 0.00 & -0.772 & 0.00 \\
\hline Adj. yield spread & -1.978 & 0.12 & 3.586 & 0.00 \\
\hline Observations & 2,074 & & 2,988 & \\
\hline Log likelihood & -387.9 & & -656.6 & \\
\hline Wald $\chi^{2}(\mathrm{j})$ & 819.3 & & 370.5 & \\
\hline pseudo $\mathrm{R}^{2}$ & 0.56 & & 0.38 & \\
\hline
\end{tabular}

Note: The models estimated here use the binomial dependent variable of whether a BOPEC upgrade or a BOPEC downgrade occurred. In the full sample of 3,010 observations, $22 \%$ are upgrades and $12 \%$ are downgrades. The explanatory variables are those described for Equation 1. BHC's with BOPEC rating 1 (5) are excluded from the upgrade (downgrade) model. The results for the interacted supervisory variables and fixed effects are not reported to conserve space. The models contained fixed effects for BHCs with public equity, BHCs with public equity for which SCAR and SCSR variables could not be properly calculated, and BHCs with pubic debt. The sample period ranges is 1990.Q1 to 1998.Q2. The model was estimated using robust standard errors and adjusting for clustered observations based on unique BHCs. 
Table 6B.

Estimation Results for the Upgrade \& Downgrade Models Past the Supervisory Threshold

\begin{tabular}{|c|c|c|c|c|}
\hline & \multicolumn{2}{|c|}{ Upgrade to BOPEC 1 or 2} & \multicolumn{2}{|c|}{ Downgrade to BOPEC 3,4 or 5} \\
\hline & coefficient & p-value & coefficient & p-value \\
\hline Lagged BOPEC & 3.376 & 0.00 & -2.246 & 0.00 \\
\hline CAMELS & -0.654 & 0.01 & 0.771 & 0.00 \\
\hline $\ln$ (assets) & -0.017 & 0.91 & -0.461 & 0.00 \\
\hline Problem loans & -57.168 & 0.00 & 43.497 & 0.00 \\
\hline Allowances & -106.400 & 0.01 & 45.377 & 0.01 \\
\hline Section 20 sub. & -8.591 & 0.00 & 2.470 & 0.01 \\
\hline Trading assets & -0.259 & 0.02 & -0.191 & 0.00 \\
\hline Double leverage & -0.039 & 0.18 & -0.119 & 0.53 \\
\hline ROA & 1.528 & 0.00 & -0.322 & 0.26 \\
\hline Equity capital & 5.804 & 0.24 & -26.693 & 0.00 \\
\hline SCSR & -0.394 & 0.28 & -1.554 & 0.00 \\
\hline SCAR & 0.368 & 0.00 & -0.829 & 0.00 \\
\hline Adj. yield spread & -2.360 & 0.22 & 1.800 & 0.06 \\
\hline Observations & 2,074 & & 2,988 & \\
\hline Log likelihood & -458.1 & & -394.2 & \\
\hline Wald $\chi^{2}(j)$ & 920.9 & & 344.0 & \\
\hline pseudo $\mathrm{R}^{2}$ & 0.39 & & 0.35 & \\
\hline
\end{tabular}

Note: In the full sample of 3,010 observations, $8 \%$ are upgrades from BOPEC 3 or worse to BOPEC 2 or better, and $5 \%$ are downgrades to BOPEC 3 or worse from BOPEC 2 or better. BHC's with BOPEC rating 1 (5) are excluded from the upgrade (downgrade) model. The explanatory variables are those described for Equation 1 . The results for the interacted supervisory variables and fixed effects are not reported to conserve space. The models contained fixed effects for BHCs with public equity, BHCs with public equity for which SCAR and SCSR variables could not be properly calculated, and BHCs with pubic debt. The sample period ranges is 1990.Q1 to 1998.Q2. The model was estimated using robust standard errors and adjusting for clustered observations based on unique BHCs. 
Table 7A.

Estimation Results for the Simplified BOM Model using Distance-to-Default Interactions with SCARs

\begin{tabular}{|c|c|c|c|c|c|c|c|}
\hline & $\begin{array}{c}\pi \text { for } \\
\text { SCAR } \\
\text { variable }\end{array}$ & $\mathrm{p}$-value & $\begin{array}{c}\alpha \text { interaction } \\
\text { with DTD } \\
\text { measure }\end{array}$ & p-value & $\pi+\alpha$ & $\begin{array}{l}\log \\
\text { likeli- } \\
\text { hood }\end{array}$ & $\begin{array}{c}\text { pseudo } \\
\mathrm{R}^{2}\end{array}$ \\
\hline $\begin{array}{l}10^{\text {th }} \\
\text { pctile }\end{array}$ & -0.421 & 0.00 & 0.137 & 0.48 & -0.284 & -972.3 & 0.31 \\
\hline $\begin{array}{l}20^{\text {th }} \\
\text { pctile }\end{array}$ & -0.406 & 0.00 & 0.022 & 0.89 & -0.384 & -972.7 & 0.31 \\
\hline $\begin{array}{l}30^{\text {th }} \\
\text { pctile }\end{array}$ & -0.423 & 0.00 & 0.054 & 0.71 & -0.369 & -972.6 & 0.31 \\
\hline $\begin{array}{l}40^{\text {th }} \\
\text { pctile }\end{array}$ & -0.431 & 0.00 & 0.058 & 0.67 & -0.373 & -972.7 & 0.31 \\
\hline $\begin{array}{l}50^{\text {th }} \\
\text { pctile }\end{array}$ & -0.418 & 0.00 & 0.030 & 0.84 & -0.388 & -972.7 & 0.31 \\
\hline $\begin{array}{l}60^{\text {th }} \\
\text { pctile }\end{array}$ & -0.313 & 0.00 & -0.114 & 0.42 & -0.427 & -972.4 & 0.31 \\
\hline $\begin{array}{l}70^{\text {th }} \\
\text { pctile }\end{array}$ & -0.271 & 0.04 & -0.155 & 0.32 & -0.426 & 972.5 & 0.31 \\
\hline $\begin{array}{l}80^{\text {th }} \\
\text { pctile }\end{array}$ & -0.286 & 0.09 & -0.126 & 0.49 & -0.412 & -972.5 & 0.31 \\
\hline $\begin{array}{l}90^{\text {th }} \\
\text { pctile }\end{array}$ & -0.197 & 0.41 & -0.214 & 0.40 & -0.411 & -972.4 & 0.31 \\
\hline
\end{tabular}

Note: The coefficient estimates presented here are for the regression in Equation 9. The securities market variable of interest is the BHC SCARs as used previously. The interacted indicator variable is equal to one if the BHC's distance-to-default (DTD) measure is in the $\mathrm{N}^{\text {th }}$ percentile of its unconditional distribution. All models are estimated with a sample of 1,266 observations. 
Table 7B

Estimation Results for the Simplified BOM Model using Distance-to-Default Interactions with the Adjusted Yield Spreads

\begin{tabular}{|c|c|c|c|c|c|c|c|}
\hline & $\begin{array}{c}\pi \text { for } \\
\text { adj. yield } \\
\text { spread }\end{array}$ & $\mathrm{p}$-value & $\begin{array}{c}\alpha \text { interaction } \\
\text { with DTD } \\
\text { measure }\end{array}$ & $\mathrm{p}$-value & $\pi+\alpha$ & $\begin{array}{c}\log \\
\text { likeli- } \\
\text { hood }\end{array}$ & $\begin{array}{c}\text { pseudo } \\
\mathrm{R}^{2}\end{array}$ \\
\hline $\begin{array}{l}10^{\text {th }} \\
\text { pctile }\end{array}$ & 0.626 & 0.56 & 8.906 & 0.00 & 9.532 & -189.5 & 0.39 \\
\hline $\begin{array}{l}20^{\text {th }} \\
\text { pctile }\end{array}$ & 0.245 & 0.86 & 1.445 & 0.56 & 1.690 & -190.3 & 0.39 \\
\hline $\begin{array}{l}30^{\text {th }} \\
\text { pctile }\end{array}$ & 1.180 & 0.55 & -0.651 & 0.77 & 0.529 & -190.5 & 0.39 \\
\hline $\begin{array}{l}40^{\text {th }} \\
\text { pctile }\end{array}$ & 1.956 & 0.22 & -1.726 & 0.36 & 0.230 & -190.1 & 0.39 \\
\hline $\begin{array}{l}50^{\text {th }} \\
\text { pctile }\end{array}$ & 2.894 & 0.01 & -3.099 & 0.05 & -0.205 & -188.8 & 0.40 \\
\hline $\begin{array}{l}60^{\text {th }} \\
\text { pctile }\end{array}$ & 1.646 & 0.16 & -1.095 & 0.54 & 0.551 & -190.5 & 0.39 \\
\hline $\begin{array}{l}70^{\text {th }} \\
\text { pctile }\end{array}$ & 1.859 & 0.21 & -1.315 & 0.52 & 0.544 & -190.4 & 0.39 \\
\hline $\begin{array}{l}80^{\text {th }} \\
\text { pctile }\end{array}$ & 0.116 & 0.06 & 0.733 & 0.76 & 0.849 & -190.6 & 0.39 \\
\hline $\begin{array}{l}90^{\text {th }} \\
\text { pctile }\end{array}$ & -1.631 & 0.50 & 2.499 & 0.33 & 0.868 & -190.5 & 0.39 \\
\hline
\end{tabular}

Note: The coefficient estimates presented here are for the regression in Equation 9. The securities market variable of interest is the BHC adjusted yield spreads as used previously. The interacted indicator variable is equal to one if the BHC's distance-to-default (DTD) measure is in the $\mathrm{N}^{\text {th }}$ percentile of its unconditional distribution. All models are estimated with a sample of 282 observations. 
Table 8A. Out-of-Sample Forecast Accuracy of the Core BOM Model

\begin{tabular}{|c|c|c|c|c|c|}
\hline \multirow[b]{2}{*}{$\begin{array}{l}\text { Signal at } \\
-4 \text { quarters }\end{array}$} & \multicolumn{5}{|c|}{ Actual Inspection Outcome } \\
\hline & $\begin{array}{c}\# \\
\text { signals }\end{array}$ & $\begin{array}{c}\text { upgrade } \\
\%\end{array}$ & $\begin{array}{c}\text { no change } \\
\%\end{array}$ & $\begin{array}{c}\text { downgrade } \\
\% \\
\end{array}$ & $\begin{array}{l}\text { Pearson } \\
\text { statistic }\end{array}$ \\
\hline upgrade & 22 & $55 \%$ & $36 \%$ & $9 \%$ & \\
\hline no change & 2,825 & $22 \%$ & $67 \%$ & $11 \%$ & \\
\hline downgrade & 31 & $3 \%$ & $29 \%$ & $68 \%$ & $145.0 *$ \\
\hline \multicolumn{6}{|l|}{$\begin{array}{l}\text { Signal at } \\
-3 \text { quarters }\end{array}$} \\
\hline upgrade & 28 & $68 \%$ & $21 \%$ & $11 \%$ & \\
\hline no change & 2,820 & $22 \%$ & $67 \%$ & $11 \%$ & \\
\hline downgrade & 30 & $0 \%$ & $17 \%$ & $83 \%$ & $254.3^{*}$ \\
\hline \multicolumn{6}{|l|}{$\begin{array}{l}\text { Signal at } \\
-2 \text { quarters }\end{array}$} \\
\hline upgrade & 45 & $80 \%$ & $13 \%$ & $7 \%$ & \\
\hline no change & 2,793 & $22 \%$ & $68 \%$ & $10 \%$ & \\
\hline downgrade & 40 & $0 \%$ & $10 \%$ & $90 \%$ & $460.1^{*}$ \\
\hline \multicolumn{6}{|l|}{$\begin{array}{l}\text { Signal at } \\
-1 \text { quarters }\end{array}$} \\
\hline upgrade & 60 & $90 \%$ & $8 \%$ & $2 \%$ & \\
\hline no change & 2,773 & $21 \%$ & $69 \%$ & $10 \%$ & \\
\hline downgrade & 45 & $0 \%$ & $9 \%$ & $91 \%$ & $624.6^{*}$ \\
\hline
\end{tabular}

Note: This table presents the forecast accuracy results based on conditioning on the adjusted BOPEC forecasts from the core BOM model at different horizons. A forecast signal is the difference between the forecasted BOPEC and the previously assigned BOPEC rating. Thus, signals of less than -1 and greater than 1 are forecasts of upgrades and downgrades, respectively. The cells in bold indicate the outcome expected, conditional on the signal. Percentages in rows may not sum to $100 \%$ due to rounding. The Pearson goodness-of-fit statistic tests the null hypothesis that the distribution of BOPEC outcomes conditional on the core model forecasts is not different from the in-sample probabilities of upgrade, no change, and downgrade (the unconditional distribution). The statistic is distributed $\chi^{2}(10) . A *$ denotes significance at the $5 \%$ level. 
Table 8B. Out-of-Sample Forecast Accuracy of the Equity BOM Model

\begin{tabular}{|c|c|c|c|c|c|c|}
\hline \multirow[b]{2}{*}{$\begin{array}{l}\text { Signal at }-4 \\
\text { quarters }\end{array}$} & \multicolumn{6}{|c|}{ Actual Inspection Outcome } \\
\hline & \# obs. & $\begin{array}{c}\text { upgrade } \\
\%\end{array}$ & $\begin{array}{c}\text { no } \\
\text { change }\end{array}$ & $\begin{array}{c}\text { downgrade } \\
\%\end{array}$ & $\begin{array}{c}\text { Pearson } \\
\text { stat. I }\end{array}$ & $\begin{array}{c}\text { Pearson } \\
\text { stat. II }\end{array}$ \\
\hline upgrade & 26 & $62 \%$ & $27 \%$ & $12 \%$ & & \\
\hline no change & 2,875 & $22 \%$ & $67 \%$ & $11 \%$ & & \\
\hline downgrade & 39 & $0 \%$ & $44 \%$ & $56 \%$ & $139.2 *$ & $10.3^{*}$ \\
\hline \multicolumn{7}{|l|}{$\begin{array}{l}\text { Signal at } \\
-3 \text { quarters }\end{array}$} \\
\hline upgrade & 31 & $71 \%$ & $19 \%$ & $10 \%$ & & \\
\hline no change & 2,870 & $22 \%$ & $68 \%$ & $11 \%$ & & \\
\hline downgrade & 39 & $0 \%$ & $15 \%$ & $85 \%$ & $336.4^{*}$ & 0.6 \\
\hline \multicolumn{7}{|l|}{$\begin{array}{l}\text { Signal at } \\
-2 \text { quarters }\end{array}$} \\
\hline upgrade & 49 & $84 \%$ & $12 \%$ & $4 \%$ & & \\
\hline no change & 2,832 & $21 \%$ & $69 \%$ & $10 \%$ & & \\
\hline downgrade & 59 & $0 \%$ & $10 \%$ & $90 \%$ & $638.0^{*}$ & 1.7 \\
\hline \multicolumn{7}{|l|}{$\begin{array}{l}\text { Signal at } \\
-1 \text { quarters }\end{array}$} \\
\hline upgrade & 69 & $91 \%$ & $7 \%$ & $1 \%$ & & \\
\hline no change & 2,803 & $21 \%$ & $69 \%$ & $10 \%$ & & \\
\hline downgrade & 68 & $0 \%$ & $18 \%$ & $82 \%$ & $747.0^{*}$ & $9.0^{*}$ \\
\hline
\end{tabular}

Note: This table presents the forecast accuracy results based on conditioning on the adjusted BOPEC forecasts from the equity BOM model at different horizons. A forecast signal is the difference between the forecasted BOPEC and the previously assigned BOPEC rating. Thus, signals of less than -1 and greater than 1 are forecasts of upgrades and downgrades, respectively. The cells in bold indicate the outcome expected, conditional on the signal. Percentages in rows may not sum to $100 \%$ due to rounding. The Pearson goodness-of-fit statistic I tests the null hypothesis that the distribution of BOPEC outcomes conditional on the equity model forecasts is not different from the in-sample probabilities of upgrade, no change, and downgrade (the unconditional distribution). The statistic is distributed $\chi^{2}(10)$. The Pearson goodness-of-fit statistic II tests the null hypothesis that the distribution of BOPEC outcomes conditional on the equity model forecasts is not different from the distribution of outcomes forecasted by the core model. The statistic is distributed $\chi^{2}(2) . A *$ denotes significance at the $5 \%$ level. 
Table 8C. Out-of-Sample Forecast Accuracy of the Debt BOM Model

\begin{tabular}{|c|c|c|c|c|c|c|}
\hline \multirow[b]{2}{*}{$\begin{array}{l}\text { Signal at } \\
-4 \text { quarters }\end{array}$} & \multicolumn{6}{|c|}{ Actual Inspection Outcomes } \\
\hline & $\begin{array}{c}\# \\
\text { obs. }\end{array}$ & $\underset{\%}{\operatorname{upgrade}}$ & $\begin{array}{c}\text { no } \\
\text { change }\end{array}$ & $\begin{array}{c}\text { downgrade } \\
\%\end{array}$ & $\begin{array}{c}\text { Pearson } \\
\text { stat. I }\end{array}$ & $\begin{array}{c}\text { Pearson } \\
\text { stat. II }\end{array}$ \\
\hline upgrade & 26 & $50 \%$ & $38 \%$ & $12 \%$ & & \\
\hline no change & 2,878 & $22 \%$ & $67 \%$ & $11 \%$ & & \\
\hline downgrade & 36 & $3 \%$ & $36 \%$ & $61 \%$ & $130.3^{*}$ & 2.4 \\
\hline \multicolumn{7}{|l|}{$\begin{array}{l}\text { Signal at } \\
\text {-3 quarters }\end{array}$} \\
\hline upgrade & 28 & $64 \%$ & $21 \%$ & $14 \%$ & & \\
\hline no change & 2,878 & $22 \%$ & $67 \%$ & $11 \%$ & & \\
\hline downgrade & 34 & $0 \%$ & $21 \%$ & $79 \%$ & $250.6^{*}$ & 1.4 \\
\hline \multicolumn{7}{|l|}{\begin{tabular}{|l} 
Signal at \\
-2 quarters \\
\end{tabular}} \\
\hline upgrade & 43 & $81 \%$ & $12 \%$ & $7 \%$ & & \\
\hline no change & 2,853 & $21 \%$ & $68 \%$ & $11 \%$ & & \\
\hline downgrade & 44 & $0 \%$ & $11 \%$ & $89 \%$ & $479.8^{*}$ & 0.5 \\
\hline \multicolumn{7}{|l|}{$\begin{array}{l}\text { Signal at } \\
-1 \text { quarters }\end{array}$} \\
\hline upgrade & 60 & $88 \%$ & $8 \%$ & $3 \%$ & & \\
\hline no change & 2,824 & $21 \%$ & $69 \%$ & $10 \%$ & & \\
\hline downgrade & 56 & $0 \%$ & $13 \%$ & $88 \%$ & $663.2^{*}$ & 3.1 \\
\hline
\end{tabular}

Note: This table presents the forecast accuracy results based on conditioning on the adjusted BOPEC forecasts from the deb BOM model at different horizons. A forecast signal is the difference between the forecasted BOPEC and the previously assigned BOPEC rating. Thus, signals of less than -1 and greater than 1 are forecasts of upgrades and downgrades, respectively. The cells in bold indicate the outcome expected, conditional on the signal. Percentages in rows may not sum to $100 \%$ due to rounding. The Pearson goodness-of-fit statistic I tests the null hypothesis that the distribution of BOPEC outcomes conditional on the debt model forecasts is not different from the in-sample probabilities of upgrade, no change, and downgrade (the unconditional distribution). The statistic is distributed $\chi^{2}(10)$. The Pearson goodness-of-fit statistic II tests the null hypothesis that the distribution of BOPEC outcomes conditional on the debt model forecasts is not different from the distribution of outcomes forecasted by the core model. The statistic is distributed $\chi^{2}(2) . A *$ denotes significance at the $5 \%$ level. 
Table 8D. Out-of-Sample Forecast Accuracy of the Extended BOM Model

\begin{tabular}{|c|c|c|c|c|c|c|}
\hline \multirow[b]{2}{*}{$\begin{array}{l}\text { Signal at } \\
-4 \text { quarters }\end{array}$} & \multicolumn{6}{|c|}{ Actual Inspection Outcomes } \\
\hline & $\begin{array}{c}\# \\
\text { obs. }\end{array}$ & $\underset{\%}{\text { upgrade }}$ & $\begin{array}{c}\text { no } \\
\text { change }\end{array}$ & $\begin{array}{c}\text { downgrade } \\
\%\end{array}$ & $\begin{array}{c}\text { Pearson } \\
\text { stat. I }\end{array}$ & $\begin{array}{c}\text { Pearson } \\
\text { stat. II }\end{array}$ \\
\hline upgrade & 28 & $57 \%$ & $36 \%$ & $7 \%$ & & \\
\hline no change & 2,813 & $22 \%$ & $67 \%$ & $11 \%$ & & \\
\hline downgrade & 37 & $0 \%$ & $43 \%$ & $57 \%$ & $126.7 *$ & $6.4^{*}$ \\
\hline \multicolumn{7}{|l|}{$\begin{array}{l}\text { Signal at } \\
\mathbf{- 3} \text { quarters }\end{array}$} \\
\hline upgrade & 31 & $68 \%$ & $267 \%$ & $6 \%$ & & \\
\hline no change & 2,808 & $22 \%$ & $67 \%$ & $11 \%$ & & \\
\hline downgrade & 39 & $0 \%$ & $23 \%$ & $77 \%$ & $270.5^{*}$ & 3.3 \\
\hline \multicolumn{7}{|l|}{$\begin{array}{l}\text { Signal at } \\
-2 \text { quarters }\end{array}$} \\
\hline upgrade & 48 & $83 \%$ & $13 \%$ & $4 \%$ & & \\
\hline no change & 2,767 & $22 \%$ & $68 \%$ & $10 \%$ & & \\
\hline downgrade & 63 & $0 \%$ & $13 \%$ & $87 \%$ & $633.1 *$ & 3.1 \\
\hline \multicolumn{7}{|l|}{$\begin{array}{l}\text { Signal at } \\
-1 \text { quarters }\end{array}$} \\
\hline upgrade & 67 & $90 \%$ & $7 \%$ & $3 \%$ & & \\
\hline no change & 2,746 & $21 \%$ & $69 \%$ & $10 \%$ & & \\
\hline downgrade & 65 & $2 \%$ & $17 \%$ & $83 \%$ & $715.5^{*}$ & $11.9^{*}$ \\
\hline
\end{tabular}

Note: This table presents the forecast accuracy results based on conditioning on the adjusted BOPEC forecasts from the extended BOM model at different horizons. A forecast signal is the difference between the forecasted BOPEC and the previously assigned BOPEC rating. Thus, signals of less than -1 and greater than 1 are forecasts of upgrades and downgrades, respectively. The cells in bold indicate the outcome expected, conditional on the signal.

Percentages in rows may not sum to $100 \%$ due to rounding. The Pearson goodness-of-fit statistic I tests the null hypothesis that the distribution of BOPEC outcomes conditional on the extended model forecasts is not different from the in-sample probabilities of upgrade, no change, and downgrade (the unconditional distribution). The statistic is distributed $\chi^{2}(10)$. The Pearson goodness-of-fit statistic II tests the null hypothesis that the distribution of BOPEC outcomes conditional on the extended model forecasts is not different from the distribution of outcomes forecasted by the core model. The statistic is distributed $\chi^{2}(2) . A *$ denotes significance at the $5 \%$ level. 
Table 9A. Improvements in BOPEC Downgrade Forecasts

\begin{tabular}{c|c|c|c} 
& Equity BOM Model & Debt BOM Model & $\begin{array}{c}\text { Debt and Equity } \\
\text { BOM Model }\end{array}$ \\
\hline 4 quarters prior & $24 \%$ & $14 \%$ & $22 \%$ \\
3 quarters prior & $28 \%$ & $10 \%$ & $31 \%$ \\
2 quarters prior & $28 \%$ & $9 \%$ & $29 \%$ \\
1 quarter prior & $24 \%$ & $5 \%$ & $25 \%$
\end{tabular}

Note: This table presents the percentage improvement in correct BOPEC downgrade signals when combining the downgrade signals from the core BOM model with those from the models incorporating securities market data. Downgrade signal is defined as forecasted rating - current rating $>0.75$. The table reports the number of downgrades correctly signaled by the alternative models and not identified by core model, expressed as a percentage of downgrades correctly identified by core model. Note that the alternative models' signals are for public BHCs only.

Table 9B.

Tradeoff between Correct and Incorrect Downgrade Forecasts

\begin{tabular}{c|c|c|c} 
& & & $\begin{array}{c}\text { Extended BOM } \\
\text { Model }\end{array}$ \\
\hline 4 quarters prior & $1 / 2$ & Debt BOM Model & $11 / 25$ \\
3 quarters prior & $17 / 12$ & $7 / 11$ & $19 / 17$ \\
2 quarters prior & $23 / 17$ & $7 / 7$ & $6 / 5$ \\
1 quarter prior & $3 / 2$ & $5 / 1$ & $5 / 3$
\end{tabular}

Note: This table presents the tradeoff between additional correct and additional incorrect BOPEC downgrade signals provided by the alternative BOM models relative to the core BOM model. A cell entry of x/y suggests that the alternative BOM model identifies $\mathrm{x}$ additional correct downgrades signals beyond those of the core model, at the rate of y additional incorrect downgrade signals. Note that the alternative models' signals are for public BHCs only. 